\title{
Design, Synthesis and Evaluation of Probes for Spatially Resolved Imaging of Enantioselective Sulfoxide Reductases
}

Anna Tokarenko, Vladimír Nosek, and Jiř́i Míšek*

Department of Organic Chemistry, Faculty of Science, Charles University in Prague, Hlavova 2030/8, 12843 Prague 2

(Czech Republic),E-mail: misek@natur.cuni.cz

Table of Contents:

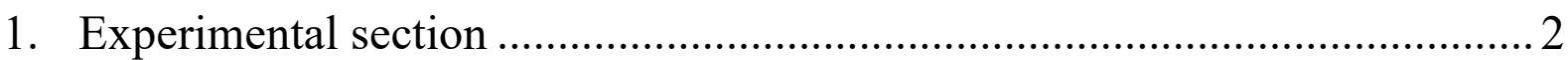

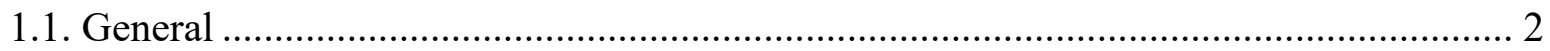

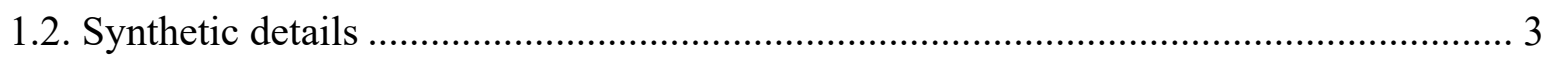

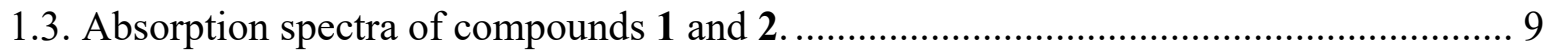

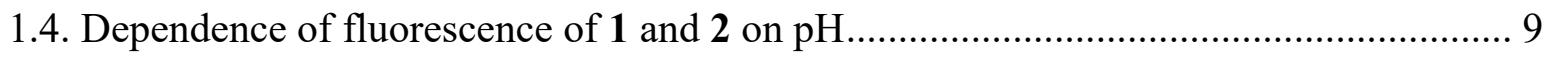

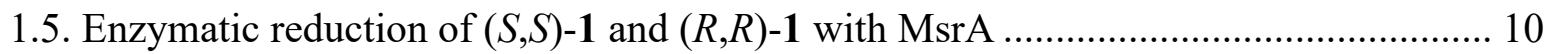

1.6. Imaging of the activity of MsrA immobilized on agarose beads ................................. 19

2. Copies of ${ }^{1} \mathrm{H}$ and ${ }^{13} \mathrm{C}$ NMR spectra ................................................ 21 


\section{Experimental section}

\subsection{General}

All starting reagents were commercially available and of analytical purity and were used without further treatment unless otherwise stated. Racemic 1-bromo-4(methylsulfinyl)benzene and $(R)$-1-bromo-4-(methylsulfinyl)benzene (ee $>99 \%$ were prepared according to the published procedure. ${ }^{1}$ Sodium phenoxide was prepared by the reaction of $\mathrm{NaH}$ with phenol in THF with subsequent solvent removal and drying at $60{ }^{\circ} \mathrm{C}$ under reduced pressure. Solvents were dried according to standard methods. All reactions were carried out with magnetic stirring under an argon atmosphere, and all Pd-catalyzed cross-coupling reactions were done in a flame-dried glassware.

NMR spectra were recorded on Bruker Avance 400 or Bruker Avance III 600 instruments; ${ }^{13} \mathrm{C}$ spectra were ${ }^{1} \mathrm{H}$ decoupled. Chemical shifts $(\delta)$ are reported in ppm relative to solvent $\left(\mathrm{CDCl}_{3}: \delta_{\mathrm{C}}=77.16 \mathrm{ppm} ; \mathrm{CD}_{3} \mathrm{OD}: \delta_{\mathrm{C}}=49.00 \mathrm{ppm}\right)$ or residual solvent peak $\left(\mathrm{CHCl}_{3}: \delta_{\mathrm{H}}=\right.$ 7.26 ppm; $\mathrm{CH}_{3} \mathrm{OH}: \delta_{\mathrm{H}}=3.31 \mathrm{ppm}$ ). Accurate mass measurements (HRMS) were obtained by ESI on Agilent 6530 Q-TOF MS spectrometer or by APCI using LTQ Orbitrap XL hybrid FT mass spectrometer. Analytical HPLC was performed under the following conditions: Agilent Eclipse plus C18 column $(3.5 \mu \mathrm{L}, 4.6 \times 100 \mathrm{~mm})$; UV/Vis detection at $\lambda_{\text {obs }}=254$ or $348 \mathrm{~nm}$;

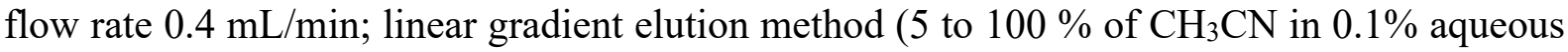
formic acid over $8 \mathrm{~min}$, then $100 \% \mathrm{CH}_{3} \mathrm{CN}$ for $5 \mathrm{~min}$ ). Analytical TLC was performed using a precoated silica gel $60 \AA \mathrm{F}_{254}$ plates $(0.2 \mathrm{~mm}$ thick) and visualized by irradiation with UV light at 254 or $366 \mathrm{~nm}$ and by dipping in stain solution (4-anisaldehyde in $\left.\mathrm{EtOH} / \mathrm{H}_{2} \mathrm{SO}_{4} / \mathrm{AcOH}\right)$ followed by heating. Preparative column chromatography was carried out using silica gel $60 \AA$ (particle size $0.063-0.200 \mathrm{~mm}$ ). Purifications by HPLC were performed on ZORBAX SB-C18 column $(5 \mu \mathrm{m}, 21.2 \times 150 \mathrm{~mm})$ with UV/Vis detection at $\lambda_{\text {obs }}=254 \mathrm{~nm}$ and flow rate of $9 \mathrm{~mL} / \mathrm{min}$. Enantiomeric excesses were determined by chiral HPLC analysis using Chiralpak IC and AD-H columns and a mixture of $n$-heptane/propan-2ol as eluent. The detailed conditions are given at the characterization part of the products. The absolute configurations of the products were determined by the comparison of chiral HPLC retention times and optical rotation values with the literature. Optical rotations were measured on an automatic polarimeter Autopol III or on a modular circular polarimeter Anton Paar MCP 5100. Fluorescence measurements were performed on AMINCO-Bowman Series 2 spectrofluorometer. UV-Vis absorption spectra were recorded on Thermo Scientific Helios $\gamma$ with wolfram and deuterium lamp. Infrared spectra were recorded on Thermo Nicolet Avatar 370 FT-IR (KBr) or Bruker Alpha FTIR (ATR) spectrometer. Melting points were measured on Büchi B-545 automatic melting point apparatus and are uncorrected. 


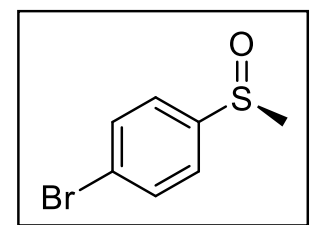

(S)-1-Bromo-4-(methylsulfinyl)benzene.

(S)-1-Bromo-4(methylsulfinyl)benzene was prepared similarly to a published procedure. $^{5}$ A $2 \mathrm{~mL}$ preculture of E. coli (msrA knock out - KEIO collection ID JW4178) ${ }^{6}$ was used to inoculate $400 \mathrm{~mL}$ of LB medium with kanamycin $(50 \mathrm{mg} / \mathrm{L})$ in a $2 \mathrm{~L}$ Erlenmeyer flask. The bacterial culture was incubated at $37^{\circ} \mathrm{C}, 200 \mathrm{rpm}$ for $6 \mathrm{~h}$ until an $\mathrm{OD}_{600}$ value of 3 was reached. Cells were then harvested by centrifugation $\left(3500 \times \mathrm{g}, 20 \mathrm{~min}, 4^{\circ} \mathrm{C}\right)$. The cell pellets were washed with M9 minimal medium (20 mL; $48 \mathrm{mM} \mathrm{Na}_{2} \mathrm{HPO}_{4}, 22 \mathrm{mM} \mathrm{KH}_{2} \mathrm{PO}_{4}, 8.6 \mathrm{mM} \mathrm{NaCl}, 18.7$ $\mathrm{mM} \mathrm{NH}_{4} \mathrm{Cl}, 2 \mathrm{mM} \mathrm{MgSO} 4,0.1 \mathrm{mM} \mathrm{CaCl}_{2}, 0.4 \%$ glycerol, $\left.\mathrm{pH} 6.95\right)$ and centrifuged $(3500 \times$ $\left.\mathrm{g}, 20 \mathrm{~min}, 4{ }^{\circ} \mathrm{C}\right)$. The cells were resuspended in $\mathrm{M} 9$ minimal medium $(20 \mathrm{~mL})$ and added to a solution of racemic 1-bromo-4-(methylsulfinyl)benzene (100 mg, $0.46 \mathrm{mmol}$ ) in M9 minimal medium $(80 \mathrm{~mL})$ and $n$-decane $(5 \mathrm{~mL})$ in a $500 \mathrm{~mL}$ Erlenmeyer flask. The reaction mixture was incubated at $37^{\circ} \mathrm{C}, 200 \mathrm{rpm}$ for $1 \mathrm{~h}$. Then, the water phase was separated from $n$-decane, centrifuged $\left(3500 \times \mathrm{g}, 20 \mathrm{~min}, 4^{\circ} \mathrm{C}\right)$, and the supernatant was extracted with $\mathrm{Et}_{2} \mathrm{O}$. Combined etheric fractions were washed with water and brine, dried over anhydrous $\mathrm{Na}_{2} \mathrm{SO}_{4}$, and concentrated by rotary evaporation under reduced pressure. The crude product was purified by column chromatography on silica gel (30 to $50 \%$ of acetone in cyclohexane) to afford $(S)$-1bromo-4-(methylsulfinyl)benzene (41 mg, $41 \%$, ee $>99 \%$ ). $[\alpha]_{D}^{25}-130\left(c=0.5, \mathrm{CHCl}_{3}\right)$ (lit: $[\alpha]_{D}^{25}-133.9\left(c=0.51, \mathrm{CHCl}_{3}\right)$ for $(S)$, ee $\left.>99 \%\right)^{7} .{ }^{1} \mathrm{H}$ NMR $\left(400 \mathrm{MHz}, \mathrm{CDCl}_{3}\right): \delta=7.68-$ $7.65(\mathrm{~m}, 2 \mathrm{H}), 7.53-7.50(\mathrm{~m}, 2 \mathrm{H}), 2.71(\mathrm{~s}, 3 \mathrm{H})$. The spectrum is in agreement with the reported data. $^{7}$ The enantiomeric excess (ee $>99 \%$ ) was determined by HPLC on IC Chiralpak ( $n$ heptane/propan-2-ol 80:20; flow rate $1 \mathrm{~mL} / \mathrm{min} ; 25^{\circ} \mathrm{C} ; \lambda=246 \mathrm{~nm} ; \mathrm{t}_{\mathrm{r}}=18.1 \mathrm{~min}$ ).

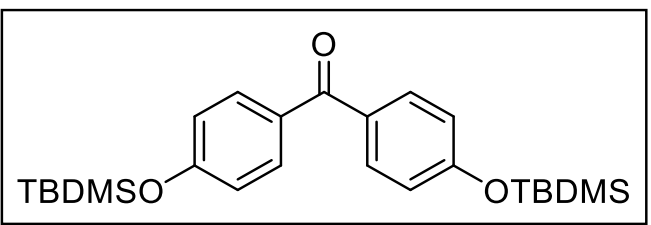

\section{Bis $\{4-[($ tert-}

butyldimethylsilyl)oxy]phenyl\}methanone (4). Compound 4 was prepared by silylation of $4,4^{\prime}-$ dihydroxybenzophenone 3 similarly to the literature procedure. ${ }^{2}$ Solution of TBDMSCl $(2.11 \mathrm{~g}, 14$ mmol) in $\mathrm{CH}_{2} \mathrm{Cl}_{2}(6 \mathrm{~mL})$ was added to a mixture of $\mathbf{3}(1.0 \mathrm{~g}, 4.7 \mathrm{mmol})$ and imidazole (953 $\mathrm{mg}, 14.0 \mathrm{mmol})$ in $\mathrm{CH}_{2} \mathrm{Cl}_{2}(12 \mathrm{~mL})$, and the resulting suspension was stirred for $1 \mathrm{~h}$ at r.t. Then, water $(50 \mathrm{~mL})$ was added, and the mixture was extracted with $\mathrm{CH}_{2} \mathrm{Cl}_{2}$. The combined organic phase was washed with brine, dried over anhydrous $\mathrm{Na}_{2} \mathrm{SO}_{4}$ and concentrated under reduced pressure. The crude product was purified by column chromatography on silica gel (0 to $4 \%$ of EtOAc in cyclohexane) to give $4(2.026 \mathrm{~g}, 4.57 \mathrm{mmol}, 98 \%)$ as a white solid. ${ }^{1} \mathrm{H}$ NMR (400 MHz, $\left.\mathrm{CDCl}_{3}\right): \delta=7.74-7.71(\mathrm{~m}, 4 \mathrm{H}), 6.91-6.88(\mathrm{~m}, 4 \mathrm{H}), 1.00(\mathrm{~s}, 18 \mathrm{H}), 0.25(\mathrm{~s}$, $12 \mathrm{H})$. The spectrum is in agreement with the reported data. ${ }^{2}$ 


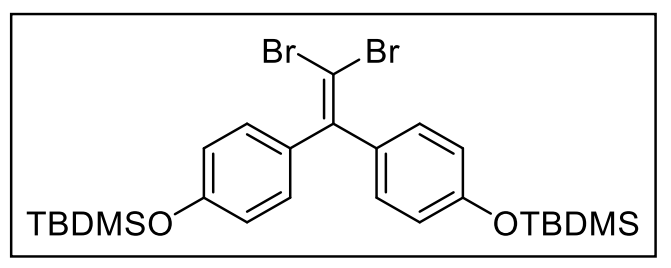

\section{$\{[(2,2-d i b r o m o e t h e n e-1,1-d i y l) b i s(4,1-$ phenylene)]bis(oxy)\}bis(tert-butyldimethylsilane)}

(5). Compound 5 was prepared similarly to a literature procedure. ${ }^{3} \mathrm{TiCl}_{4}(0.3 \mathrm{~mL}, 2.70 \mathrm{mmol})$ was added to $\mathrm{Mg}$ powder $(228 \mathrm{mg}, 9.00 \mathrm{mmol})$ suspended in dry $\mathrm{CH}_{2} \mathrm{Cl}_{2}(3 \mathrm{~mL})$ at $0{ }^{\circ} \mathrm{C}$. After $5 \mathrm{~min}$, a solution of $4(398 \mathrm{mg}, 0.90 \mathrm{mmol})$ and $\mathrm{CHBr}_{3}(0.28 \mathrm{~mL}, 3.15 \mathrm{mmol})$ in a mixture of dry $\mathrm{CH}_{2} \mathrm{Cl}_{2}(1 \mathrm{~mL})$ and dry DME $(1.1 \mathrm{~mL})$ was introduced, and the resulting suspension was stirred at $0{ }^{\circ} \mathrm{C}$ for $90 \mathrm{~min}$. After that, an icecold sat. aq. $\mathrm{K}_{2} \mathrm{CO}_{3}$ solution was slowly added, and the reaction mixture was warmed to r.t. and extracted with EtOAc. The combined organic phase was washed with brine, dried over anhydrous $\mathrm{Na}_{2} \mathrm{SO}_{4}$, and concentrated in vacuo. The crude product was subjected to column chromatography on silica gel ( 0 to $10 \%$ of $\mathrm{CH}_{2} \mathrm{Cl}_{2}$ in cyclohexane) to afford $\mathbf{5}$ (350 $\mathrm{mg}, 0.59$ mmol, $65 \%$ ) as an off-white solid (m.p. $\left.110-111{ }^{\circ} \mathrm{C}\right) .{ }^{1} \mathrm{H}$ NMR $\left(400 \mathrm{MHz}, \mathrm{CDCl}_{3}\right): \delta=$ 7.16-7.12 (m, 4H), 6.79-6.75 (m, 4H), $0.97(\mathrm{~s}, 18 \mathrm{H}), 0.20(\mathrm{~s}, 12 \mathrm{H}) .{ }^{13} \mathrm{C}\left\{{ }^{1} \mathrm{H}\right\}$ NMR $(101$ $\mathrm{MHz}, \mathrm{CDCl}_{3}$ ): $\delta=155.5,147.4,134.6,130.5,119.7,88.6,25.8,18.3,-4.2$. HRMS (APCI): $m / z \mathrm{M}^{+}$calcd for $\mathrm{C}_{26} \mathrm{H}_{38} \mathrm{O}_{2}{ }^{79} \mathrm{Br}_{2} \mathrm{Si}_{2}{ }^{+}:$596.0772; found: 596.0772. IR (KBr): $v=3035,2956$, $2929,2885,2856,1894,1776,1658,1603,1508,1257,1167 \mathrm{~cm}^{-1}$.

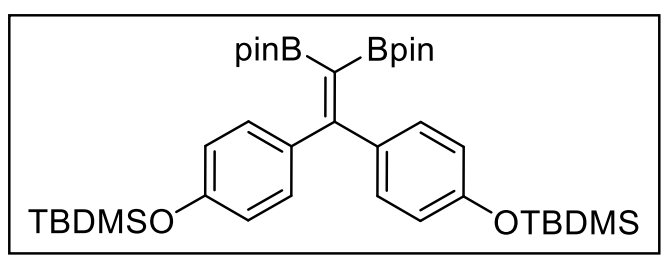

\section{(\{[2,2-bis $(4,4,5,5$-tetramethyl-1,3,2-}

\section{dioxaborolan-2-yl)ethene-1,1-diyl]bis[4,1-} phenylene]\}bis $\{0 x y\})$ bis(tert-butyldimethylsilane)

(6). Boronate 6 was obtained analogously to a published procedure. ${ }^{4}$ A mixture of $5(342 \mathrm{mg}, 0.57$ mmol), bis(pinacolato)diboron (589 $\mathrm{mg}, 2.28 \mathrm{mmol}$ ), sodium phenoxide (265 $\mathrm{mg}, 2.28$ $\mathrm{mmol}), \mathrm{Pd}\left(\mathrm{PPh}_{3}\right)_{2} \mathrm{Cl}_{2}(20 \mathrm{mg}, 0.029 \mathrm{mmol})$ and $\mathrm{PPh}_{3}(15 \mathrm{mg}, 0.057 \mathrm{mmol})$ in dry CPME (7.5 $\mathrm{mL}$ ) was refluxed for $4 \mathrm{~h}$ (oil bath). After cooling down to r.t., the reaction mixture was dissolved in EtOAc, filtered through a plug of celite and concentrated by rotary evaporation under reduced pressure. The residue was purified by column chromatography on silica gel (2 to $10 \%$ of EtOAc in cyclohexane) to give $6(280 \mathrm{mg}, 0.40 \mathrm{mmol}, 71 \%)$ as a pale yellow solid (m.p. 193-195 $\left.{ }^{\circ} \mathrm{C}\right) .{ }^{1} \mathrm{H}$ NMR $\left(400 \mathrm{MHz}, \mathrm{CDCl}_{3}\right): \delta=7.11-7.07(\mathrm{~m}, 4 \mathrm{H}), 6.71-6.67(\mathrm{~m}, 4 \mathrm{H})$, $1.15(\mathrm{~s}, 24 \mathrm{H}), 0.97(\mathrm{~s}, 18 \mathrm{H}), 0.17(\mathrm{~s}, 12 \mathrm{H}) .{ }^{13} \mathrm{C}\left\{{ }^{1} \mathrm{H}\right\} \mathrm{NMR}\left(101 \mathrm{MHz}, \mathrm{CDCl}_{3}\right): \delta=164.7$, 155.7, 138.3, 131.1, 119.2, 83.1, 25.8, 24.7, 18.4, -4.3. HRMS (ESI): $m / z[\mathrm{M}+\mathrm{H}]^{+}$calcd for $\mathrm{C}_{38} \mathrm{H}_{63} \mathrm{~B}_{2} \mathrm{O}_{6} \mathrm{Si}_{2}^{+}$: 693,4344; found: 693,4343. IR (KBr): $v=3057,3030,2978,2954,2927$, 2858, 1603, 1506, 1296, 1254, $1146 \mathrm{~cm}^{-1}$.

General procedure: Suzuki-Miyaura cross-coupling reaction and subsequent removal of silyl protecting groups. A mixture of $6(50 \mathrm{mg}, 0.072 \mathrm{mmol})$, arylbromide $(0.288 \mathrm{mmol})$, $\mathrm{Pd}(\mathrm{dppf}) \mathrm{Cl}_{2}(2.5 \mathrm{mg}, 3.6 \mu \mathrm{mol})$ and $\mathrm{Cs}_{2} \mathrm{CO}_{3}(117 \mathrm{mg}, 0.360 \mathrm{mmol})$ in 1,4-dioxane/water 95:5 (1.5 mL; deoxygenated using a freeze-pump-thaw technique) was stirred at $70{ }^{\circ} \mathrm{C}$ for $20 \mathrm{~h}$ (oil bath). After cooling down to r.t., the reaction mixture was diluted with $\mathrm{CH}_{2} \mathrm{Cl}_{2}$, filtered through a plug of celite and concentrated in vacuo. The crude product was redissolved in THF $(2 \mathrm{~mL})$ and treated with TBAF $(216 \mu \mathrm{L}, 0.216 \mathrm{mmol} ; 1 \mathrm{M}$ in THF) at r.t. After stirring for 2 h, sat. aq. $\mathrm{NH}_{4} \mathrm{Cl}$ solution was added, and the mixture was extracted with EtOAc. The 
combined organic phase was washed with brine, dried over anhydrous $\mathrm{MgSO}_{4}$, and concentrated under reduced pressure. The crude product was purified by HPLC.

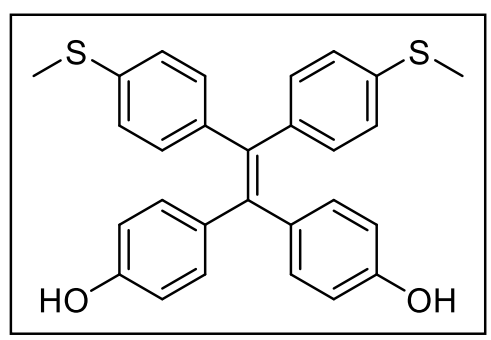

\section{4,4'-\{2,2-bis[4-(methylsulfanyl)phenyl]ethene-1,1-}

diyl\}diphenol (2). Sulfide 2 was prepared from 4bromothioanisole $(60 \mathrm{mg}, 0.288 \mathrm{mmol})$ using the general procedure. HPLC purification (50 to $100 \%$ of $\mathrm{CH}_{3} \mathrm{CN}$ in water over $10 \mathrm{~min}$, then $100 \% \mathrm{CH}_{3} \mathrm{CN}$ for $3 \mathrm{~min}$ ) afforded 2 (24 mg, $0.053 \mathrm{mmol}, 73 \%$ ) as a white solid (m.p. 203-207 $\left.{ }^{\circ} \mathrm{C}\right) .{ }^{1} \mathrm{H}$ NMR $\left(400 \mathrm{MHz}, \mathrm{CD}_{3} \mathrm{OD}\right): \delta=6.98(\mathrm{~d}, J=8.4 \mathrm{~Hz}$, $4 \mathrm{H}), 6.89(\mathrm{~d}, J=8.4 \mathrm{~Hz}, 4 \mathrm{H}), 6.81(\mathrm{~d}, J=8.6 \mathrm{~Hz}, 4 \mathrm{H}), 6.52(\mathrm{~d}, J=8.6 \mathrm{~Hz}, 4 \mathrm{H}), 2.40$ (s, 6H). ${ }^{13} \mathrm{C}\left\{{ }^{1} \mathrm{H}\right\}$ NMR $\left(101 \mathrm{MHz}, \mathrm{CD}_{3} \mathrm{OD}\right): \delta=157.3,142.6,142.2,138.6,137.7,136.5,133.7$, 133.0, 126.7, 115.5, 15.5. HRMS (ESI): $m / z \mathrm{M}^{+}$calcd for $\mathrm{C}_{28} \mathrm{H}_{24} \mathrm{O}_{2} \mathrm{~S}_{2}{ }^{+}$: 456,1212; found: 456,1214. IR (KBr): $v=3535,3359,2918,1890,1606,1506,1437,1254,1213,1167 \mathrm{~cm}^{-1}$. UV-Vis $\lambda_{\max }(\mathrm{MeOH}): 340 \mathrm{~nm}\left(\varepsilon / 10^{4} \mathrm{M}^{-1} \mathrm{~cm}^{-1}: 2.0\right)$.

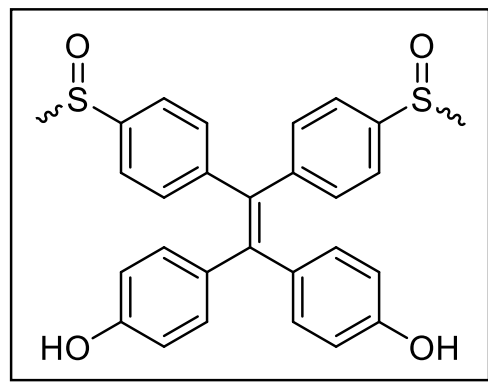

\section{4,4'-\{2,2-bis [4-(methylsulfinyl)phenyl]ethene-1,1-}

diyl\}diphenol (1). Compound 1 was prepared from racemic 1bromo-4-(methylsulfinyl)benzene $(63 \mathrm{mg}, \quad 0.288 \mathrm{mmol})$ according to the general procedure. HPLC purification (30 to $50 \%$ of $\mathrm{CH}_{3} \mathrm{CN}$ in water over $10 \mathrm{~min}$ ) afforded sulfoxide 1 (24 mg, 0.049 mmol, $68 \%$ ) as a yellow solid (m.p. 175-180 $\left.{ }^{\circ} \mathrm{C}\right) .{ }^{1} \mathrm{H}$ NMR (400 MHz, $\left.\mathrm{CD}_{3} \mathrm{OD}\right): \delta=7.50-7.46(\mathrm{~m}, 4 \mathrm{H})$, 7.24-7.20 (m, 4H), 6.85-6.82 (m, 4H), 6.56-6.52 (m, 4H), $2.76(\mathrm{~s}, 6 \mathrm{H}) .{ }^{13} \mathrm{C}\left\{{ }^{1} \mathrm{H}\right\}$ NMR (101 MHz, CD $\left.{ }_{3} \mathrm{OD}\right): \delta=158.0,149.1,146.0,143.5,136.9$, 135.3, 133.8, 133.6, 124.6, 115.7, 43.3. HRMS (ESI): $\mathrm{m} / z[\mathrm{M}+\mathrm{H}]^{+}$calcd for $\mathrm{C}_{28} \mathrm{H}_{25} \mathrm{O}_{4} \mathrm{~S}_{2}{ }^{+}$: 489,1189; found: 489,1187. IR (KBr): $v=3268,2806,2675,1900,1606,1510,1267,1234$, $1028,1011 \mathrm{~cm}^{-1}$. UV-Vis $\lambda_{\max }(\mathrm{MeOH}): 340 \mathrm{~nm}\left(\varepsilon / 10^{4} \mathrm{M}^{-1} \mathrm{~cm}^{-1}: 1.8\right)$.

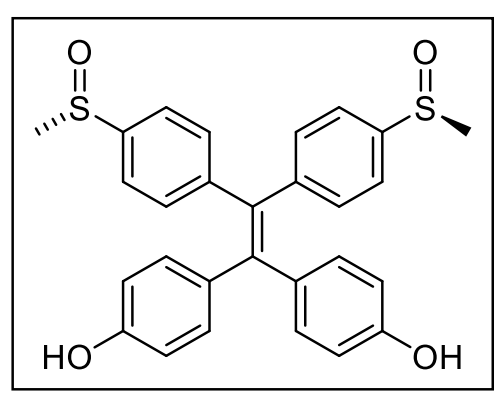

\section{$(S, S)-4,4$ '-\{2,2-bis[4-(methylsulfinyl)phenyl]ethene-1,1-} diyl\}diphenol $((S, S)-1)$. Sulfoxide $(S, S)$-1 was prepared from (S)-1-bromo-4-(methylsulfinyl)benzene (63 mg, $0.288 \mathrm{mmol})$ according to the general procedure. HPLC purification (30 to $50 \%$ of $\mathrm{CH}_{3} \mathrm{CN}$ in water over $\left.10 \mathrm{~min}\right)$ afforded $(S, S)-\mathbf{1}(22$ $\mathrm{mg}, 0.045 \mathrm{mmol}, 63 \%$, ee $>99 \%$ ) as a yellow solid (m.p. $\left.176-180{ }^{\circ} \mathrm{C}\right) .[\alpha]_{D}^{25}-97.2\left(c=0.083, \mathrm{CD}_{3} \mathrm{OD}\right) .{ }^{1} \mathrm{H}$ NMR $(600$ $\left.\mathrm{MHz}, \mathrm{CD}_{3} \mathrm{OD}\right): \delta=7.49-7.47(\mathrm{~m}, 4 \mathrm{H}), 7.23-7.21(\mathrm{~m}, 4 \mathrm{H})$, 6.85-6.82 (m, 4H), 6.55-6.53 (m, 4H), $2.76(\mathrm{~s}, 6 \mathrm{H}) .{ }^{13} \mathrm{C}\left\{{ }^{1} \mathrm{H}\right\}$ NMR $\left(151 \mathrm{MHz}, \mathrm{CD}_{3} \mathrm{OD}\right): \delta=$ $158.0,149.2,146.0,143.5,136.9,135.3,133.8,133.6,124.6,115.7,43.3$. HRMS (ESI): $m / z$ $[\mathrm{M}+\mathrm{H}]^{+}$calcd for $\mathrm{C}_{28} \mathrm{H}_{25} \mathrm{O}_{4} \mathrm{~S}_{2}{ }^{+}: 489,1189$; found: 489,1192. IR (ATR): $v=3180,2920,2850$, 1606, 1508, 1259, 1234, 1023, $1009 \mathrm{~cm}^{-1}$. UV-Vis $\lambda_{\max }(\mathrm{MeOH}): 340 \mathrm{~nm}\left(\varepsilon / 10^{4} \mathrm{M}^{-1} \mathrm{~cm}^{-1}: 1.8\right)$. 
The enantiomeric excess (ee $>99 \%$ ) was determined by HPLC on AD-H Chiralpak ( $n$ heptane/propan-2-ol 80:20; flow rate $1 \mathrm{~mL} / \mathrm{min} ; 25^{\circ} \mathrm{C} ; \lambda=365 \mathrm{~nm} ; \mathrm{t}_{\mathrm{r}}=17.1 \mathrm{~min}$ ).<smiles>CS(=O)c1ccc(C(=C(c2ccc(O)cc2)c2ccc(O)cc2)c2ccc(S(C)(=O)=O)cc2)cc1</smiles>

$(R, R)-4,4 '-\{2,2-b i s[4-(m e t h y l s u l f i n y l) p h e n y l]$ ethene-1,1diyl\}diphenol $((\boldsymbol{R}, \boldsymbol{R})-\mathbf{1})$. Sulfoxide $(R, R)-\mathbf{1}$ was prepared from $(R)$-1-bromo-4-(methylsulfinyl)benzene (63 mg, 0.288 mmol) according to the general procedure. HPLC purification (30 to $50 \%$ of $\mathrm{CH}_{3} \mathrm{CN}$ in water over $10 \mathrm{~min}$ ) afforded $(R, R)-\mathbf{1}$ (25 mg, $0.051 \mathrm{mmol}, 71 \%$, ee $>99 \%$ ) as a yellow solid. $[\alpha]_{D}^{25}+114.5\left(c=0.055, \mathrm{CD}_{3} \mathrm{OD}\right)$. The enantiomeric excess (ee $>99 \%$ ) was determined by HPLC on AD-H Chiralpak ( $n$ heptane/propan-2-ol 80:20; flow rate $1 \mathrm{~mL} / \mathrm{min} ; 25^{\circ} \mathrm{C} ; \lambda=365 \mathrm{~nm} ; \mathrm{t}_{\mathrm{r}}=34.1 \mathrm{~min}$ ). All other spectra were identical with $(S, S)-\mathbf{1}$. 

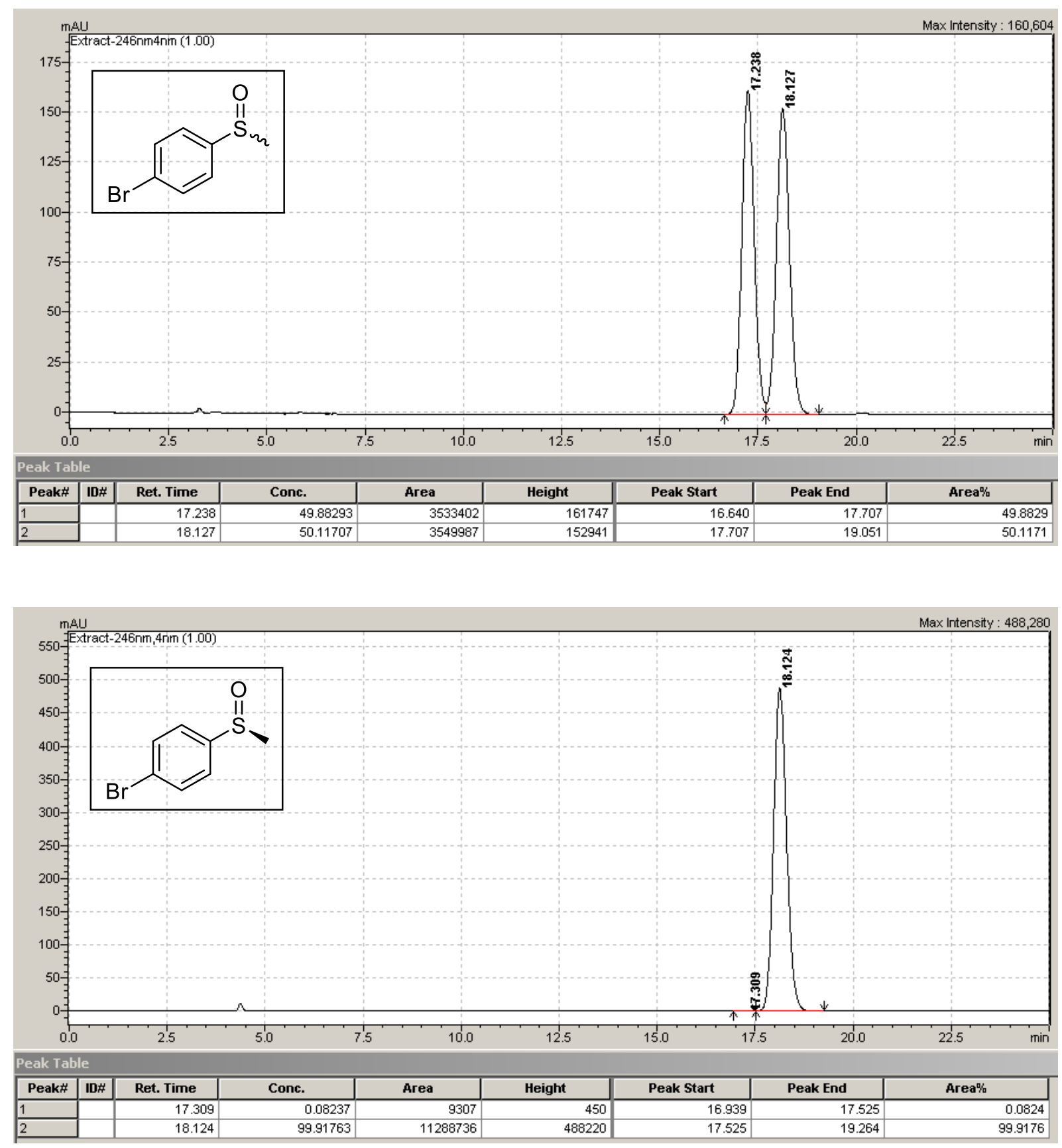

Figure S1. HPLC chromatograms of racemic 1-bromo-4-(methylsulfinyl)benzene (top) and (S)-1-bromo-4-(methylsulfinyl)benzene (bottom). IC column ( $n$-heptane/propan-2-ol 80:20, $\lambda$ $\left.=246 \mathrm{~nm}, 1 \mathrm{~mL} / \mathrm{min}, 25^{\circ} \mathrm{C}\right)$. 

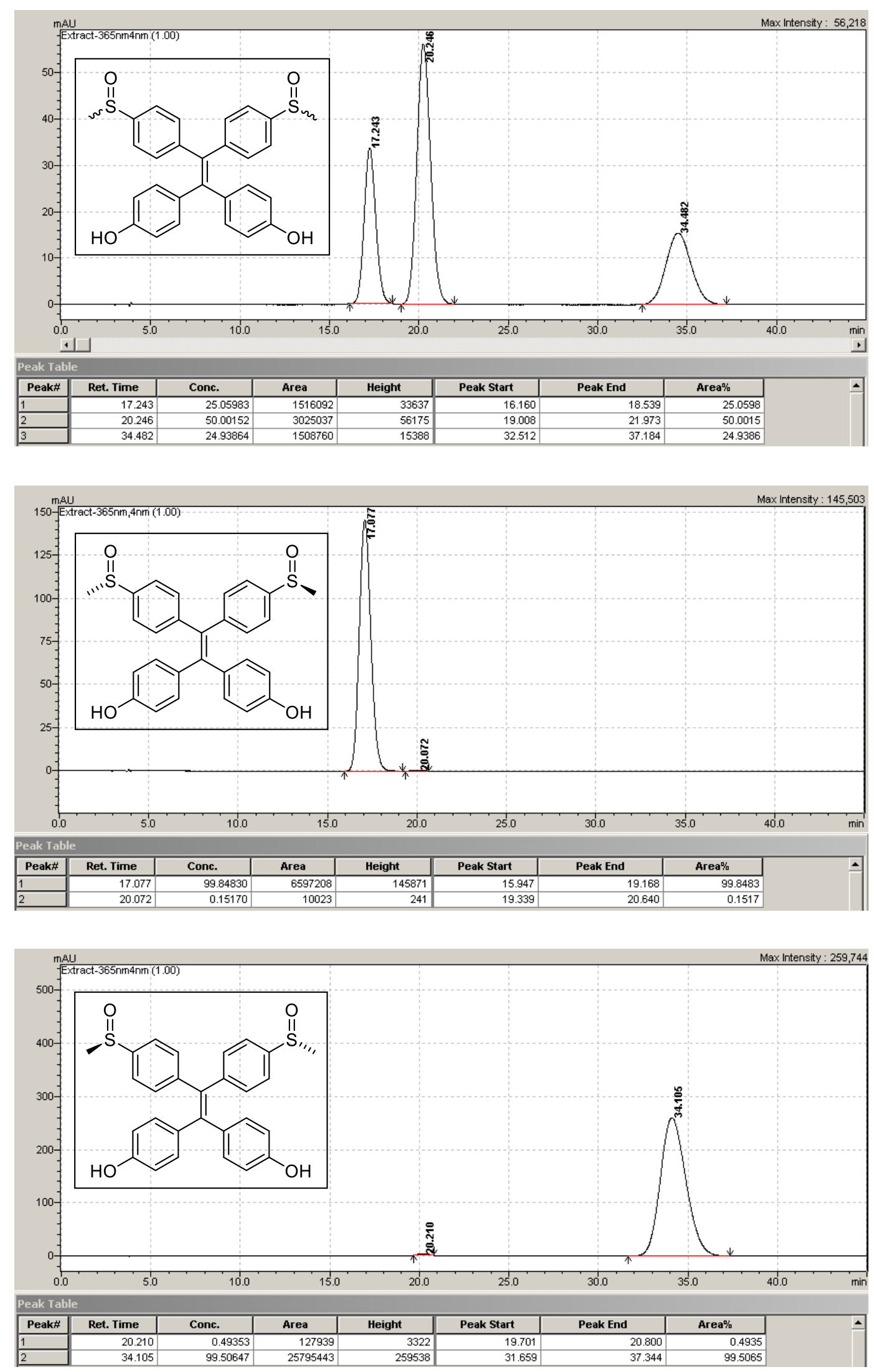

Figure S2. HPLC chromatograms of rac-1 (top), $(S, S)-\mathbf{1}$ (middle) and (R,R)-1 (bottom). AD$\mathrm{H}$ column (n-heptane/propan-2-ol 80:20, $\lambda=365 \mathrm{~nm}, 1 \mathrm{~mL} / \mathrm{min}, 25{ }^{\circ} \mathrm{C}$ ). 


\subsection{Absorption spectra of compounds 1 and 2.}

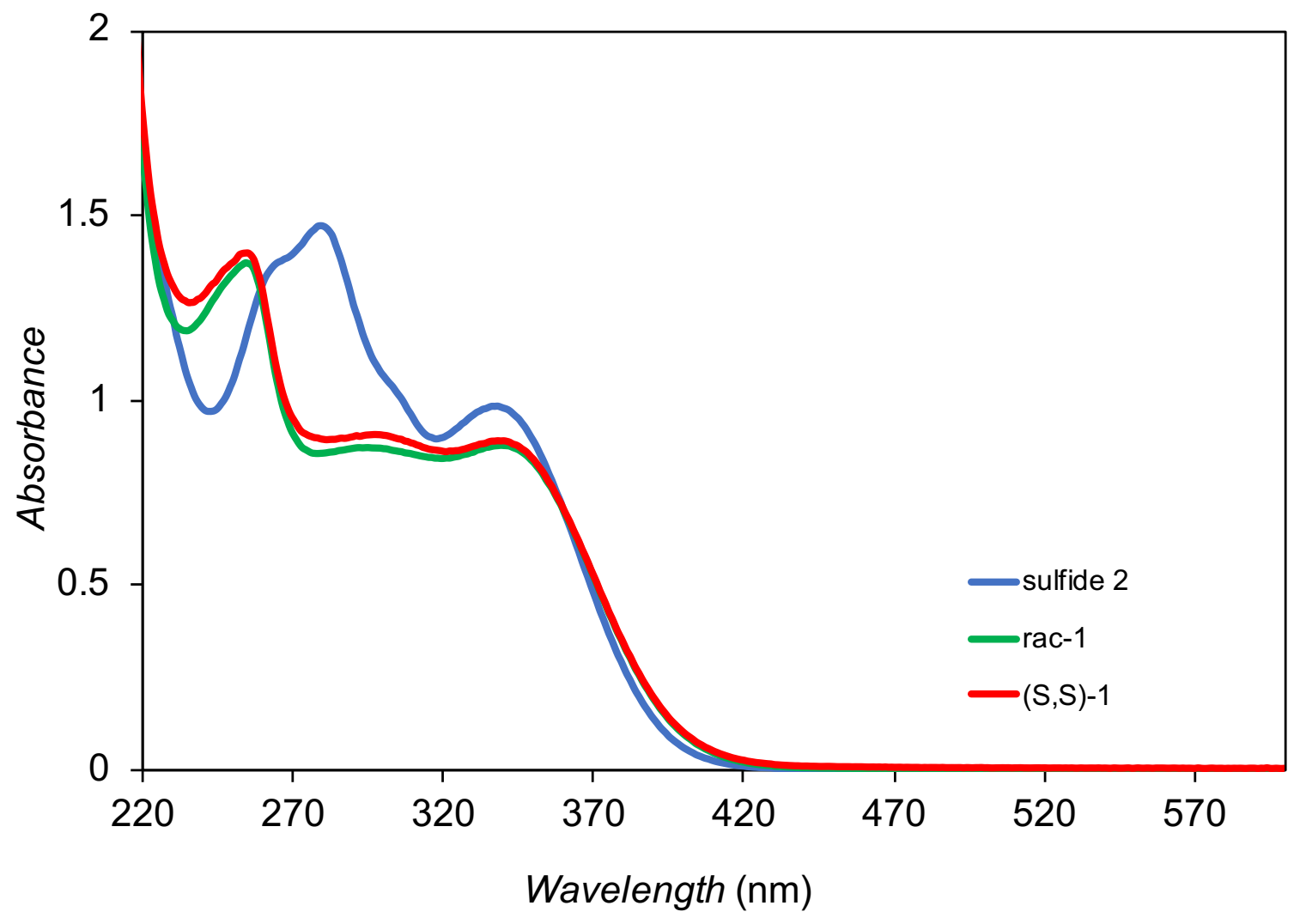

Figure S3. Absorption spectra of compounds 2, rac-1 and $(S, S)-\mathbf{1}$ recorded in $\mathrm{MeOH}$ at 50 $\mu \mathrm{M}$ concentration at room temperature.

\subsection{Dependence of fluorescence of 1 and 2 on $\mathrm{pH}$}

A stock solution of sulfoxide rac-1 (40 $\mu \mathrm{L}, 5 \mathrm{mM}$ in $\mathrm{MeOH} ; 200 \mu \mathrm{M}$ final concentration) or sulfide 2 (40 $\mu \mathrm{L}, 1.25 \mathrm{mM}$ in $\mathrm{MeOH} ; 50 \mu \mathrm{M}$ final concentration) was added to a buffer (960 $\mu \mathrm{L}$; prepared according to the literature procedure $)^{8}$ in a $1 \mathrm{~cm}$ quartz cuvette. The resulting solution/suspension was properly mixed, and the emission spectra $\left(\lambda_{\mathrm{exc}}=356 \mathrm{~nm}\right)$ were recorded in air at r.t. (Figure S4). 
(a)

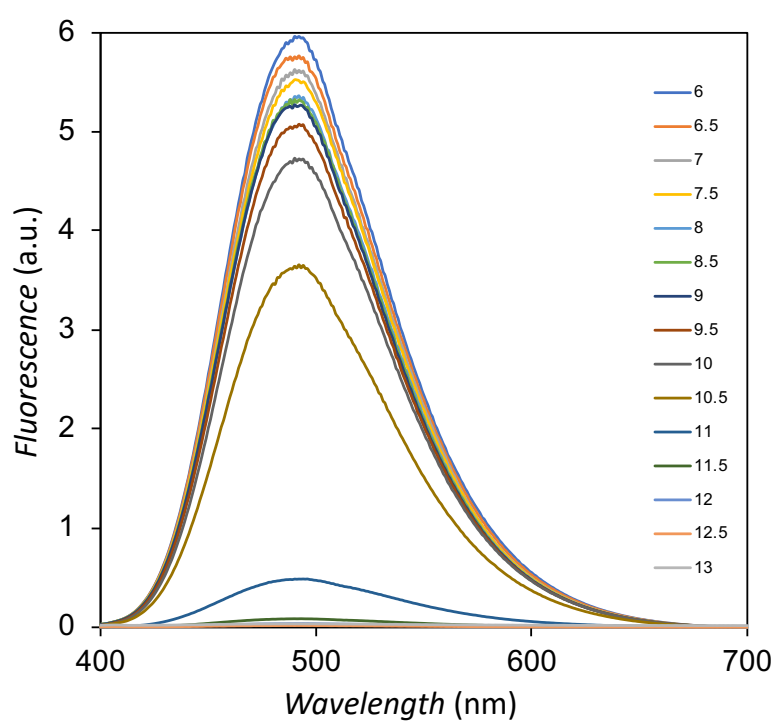

(b)

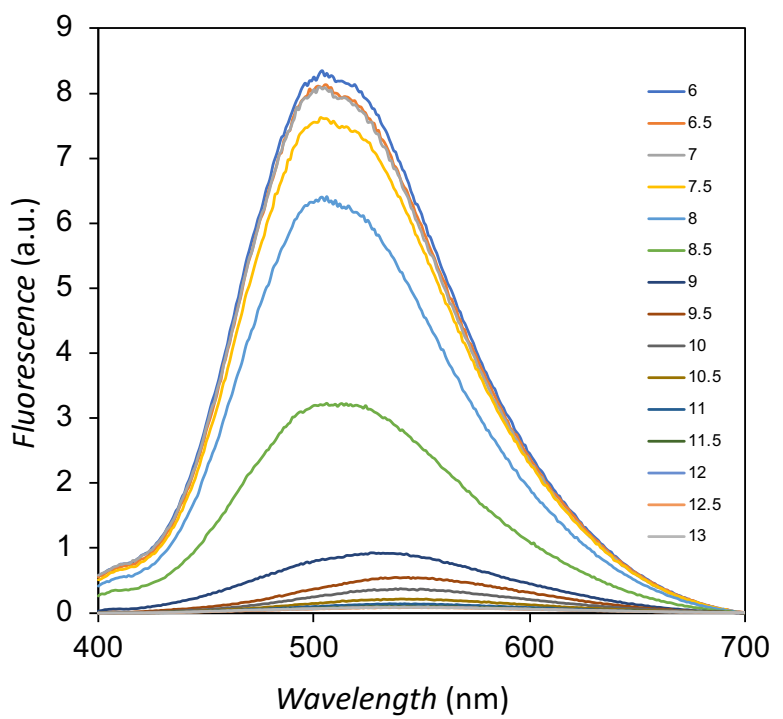

Figure S4. Emission spectra of rac-1 (a) and 2 (b) at different $\mathrm{pH}$.

\subsection{Enzymatic reduction of $(S, S)-1$ and $(R, R)-1$ with MsrA}

MsrA (15 $\mu \mathrm{L} ; 42 \mu \mathrm{M} ; 0.7 \mu \mathrm{M}$ final concentration; prepared and purified according to the published procedure $)^{7}$ was added to a solution of $(S, S)-\mathbf{1}$ or $(R, R)-\mathbf{1}(45 \mu \mathrm{L}, 1 \mathrm{mM}$ in $\mathrm{MeOH}$; $50 \mu \mathrm{M}$ final concentration) in Tris buffer $(840 \mu \mathrm{L} ; 89 \mathrm{mM}$ Tris, pH 8) with DTT $(20 \mathrm{mM})$. The mixture was gently mixed and incubated at $37^{\circ} \mathrm{C}, 300 \mathrm{RPM}$. Aliquots $(40 \mu \mathrm{L})$ of the reaction mixture were taken at different times of incubation, diluted with $\mathrm{MeOH}(120 \mu \mathrm{L})$ and analyzed using analytical HPLC-MS (Figures S5-S12). For the fluorescence measurements, the aliquots $(600 \mu \mathrm{L})$ of the reaction mixture were taken after $30 \mathrm{~min}$ of incubation, transferred to a $1 \mathrm{~cm}$ quartz cuvette, properly mixed, and the emission spectra $\left(\lambda_{\mathrm{exc}}=356 \mathrm{~nm}\right)$ were recorded in air at r.t. (Figure 3). For in situ measurement of kinetics, samples were prepared as mentioned above and placed in a fluorometer. Intensity of fluorescence at $488 \mathrm{~nm}$ $\left(\lambda_{\text {exc }}=356 \mathrm{~nm}\right)$ was recorded every $30 \mathrm{~s}$ in air at r.t. (Figure S13a). All experiments were done in triplicate. For the centrifugation and filtration experiments, fluorescent samples of $(S, S)$-1 after the reaction with MsrA were either centrifuged at $13000 \times \mathrm{g}$ for $30 \mathrm{~min}$ or filtered through $0.2 \mu \mathrm{m}$ PES membrane filter. Emission spectra $\left(\lambda_{\text {exc }}=356 \mathrm{~nm}\right)$ of the solutions were recorded in air at r.t. (Figure S13b). 


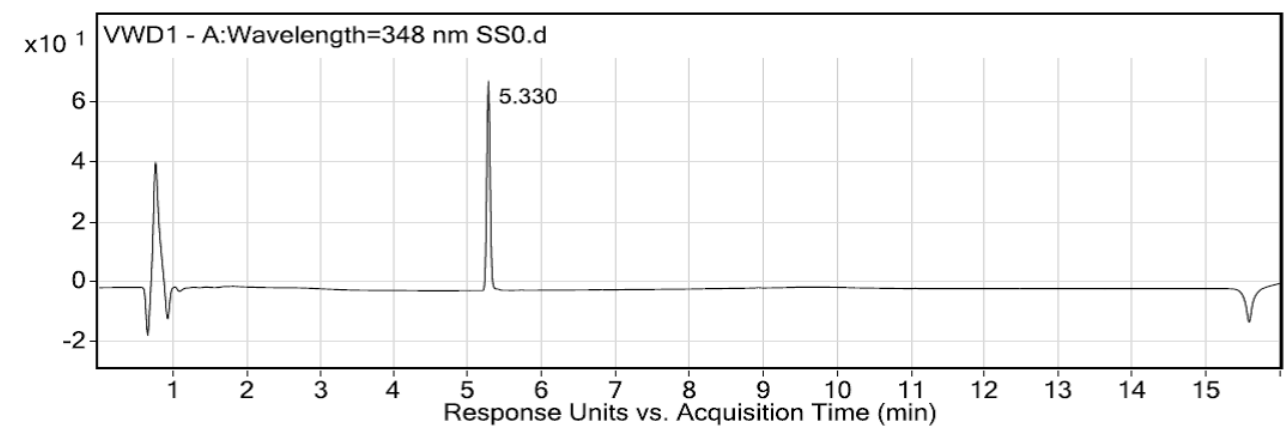

User Spectra

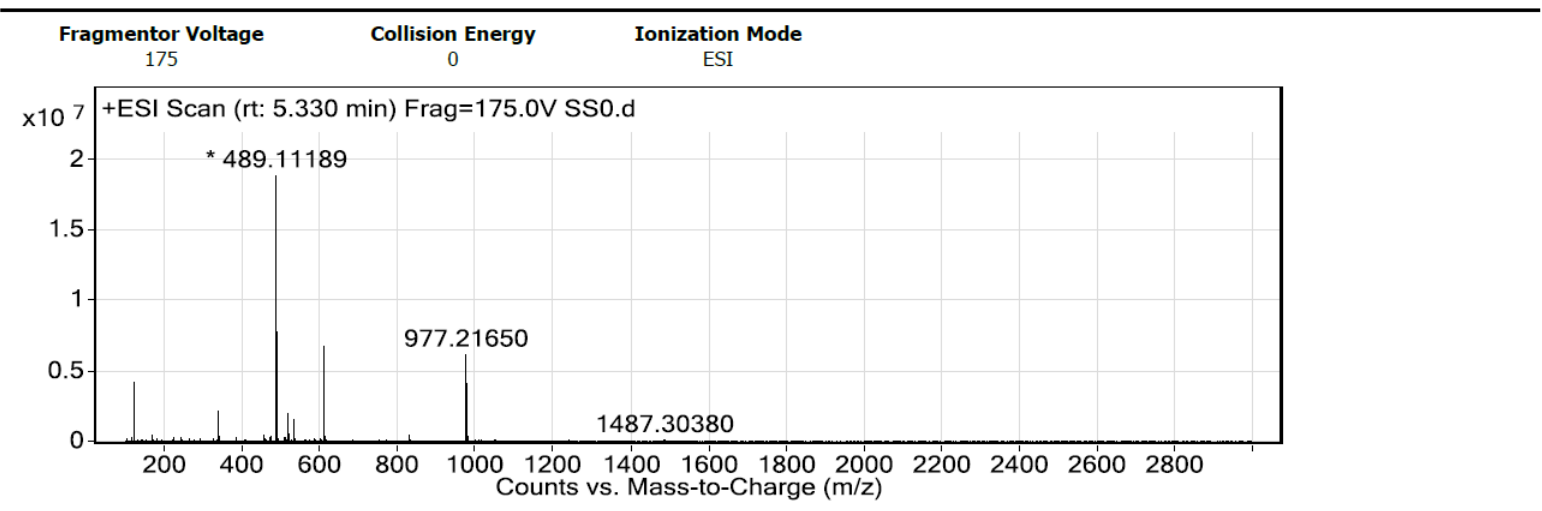

Figure S5. HPLC-MS chromatogram of $(S, S)$-1 before the reaction with MsrA. 


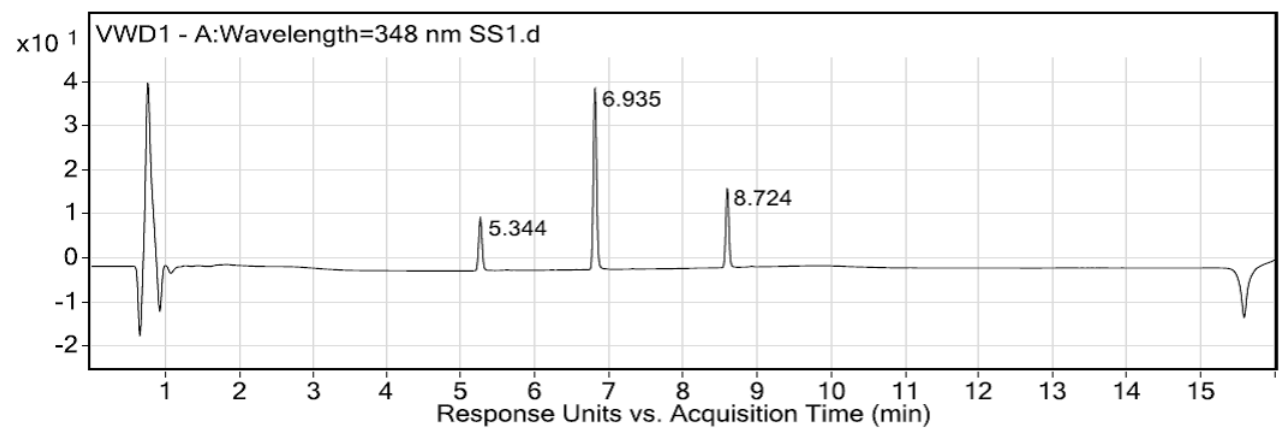

User Spectra
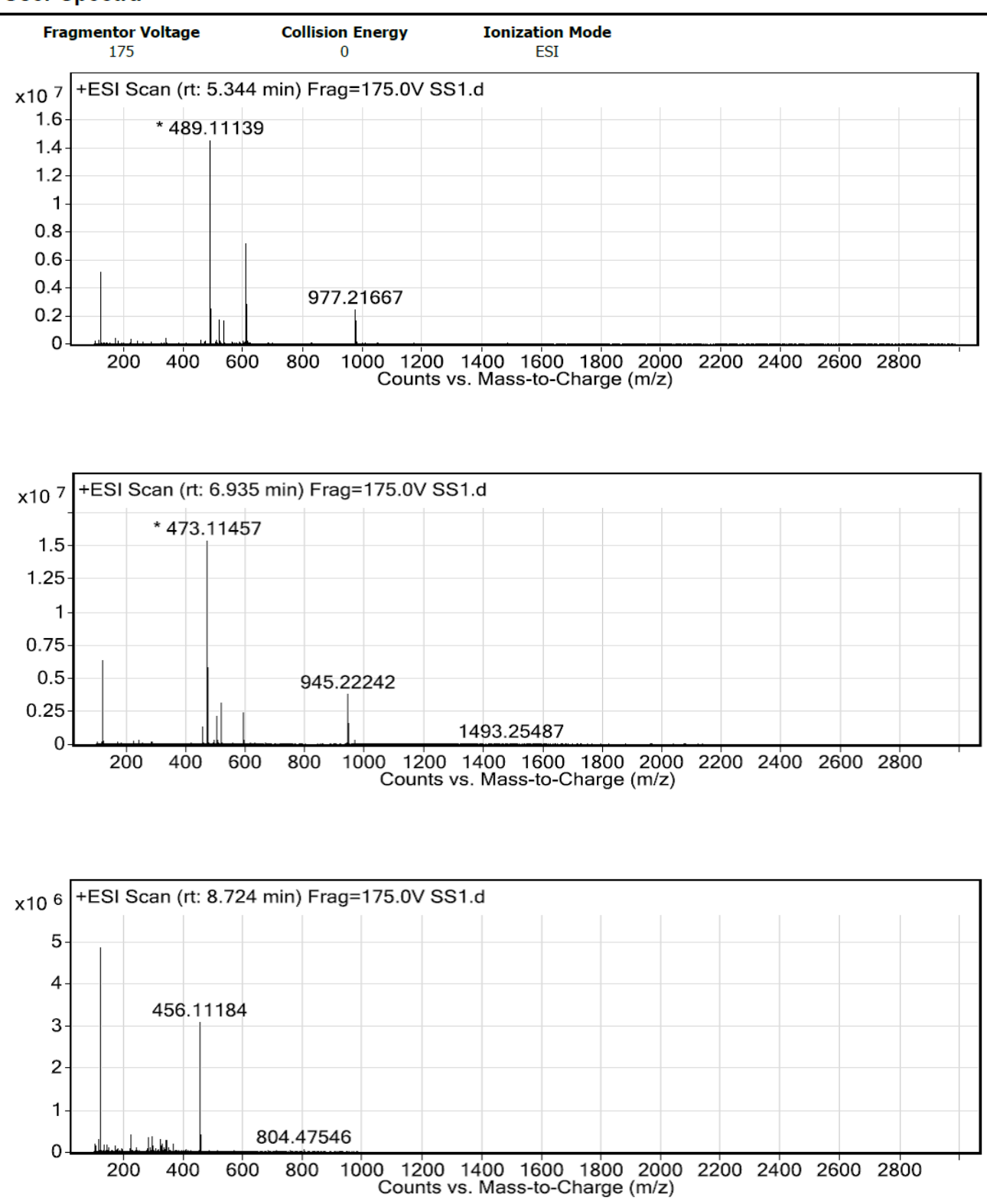

Figure S6. HPLC-MS chromatogram of $(S, S)$-1 after 1 min reaction with MsrA. 


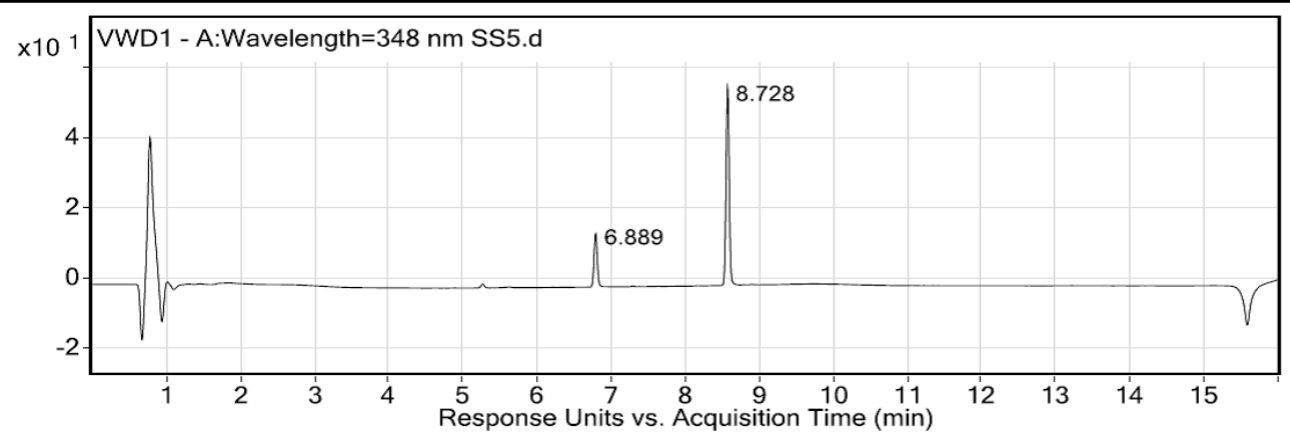

\section{User Spectra}
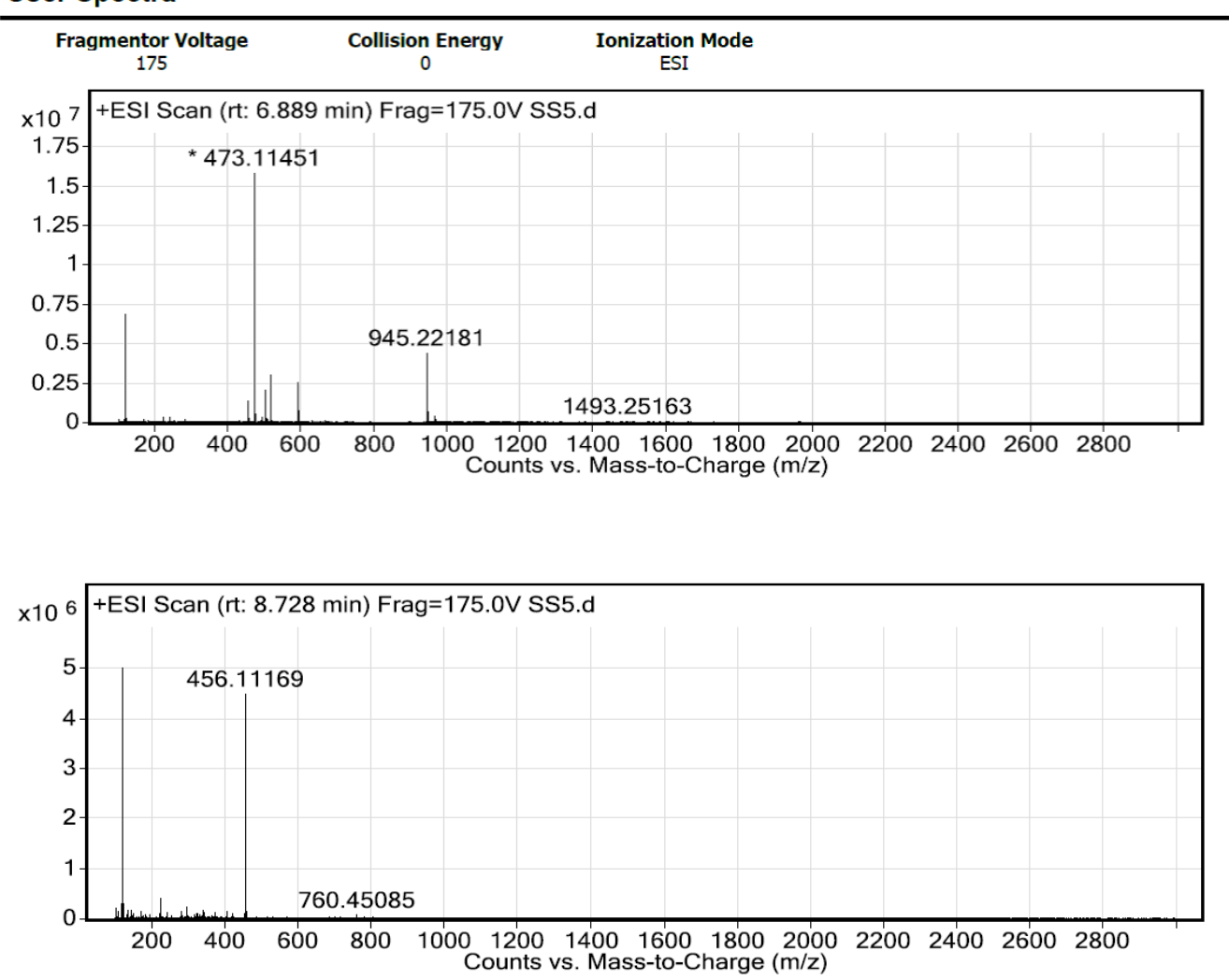

Figure S7. HPLC-MS chromatogram of $(S, S)$-1 after 5 min reaction with MsrA. 


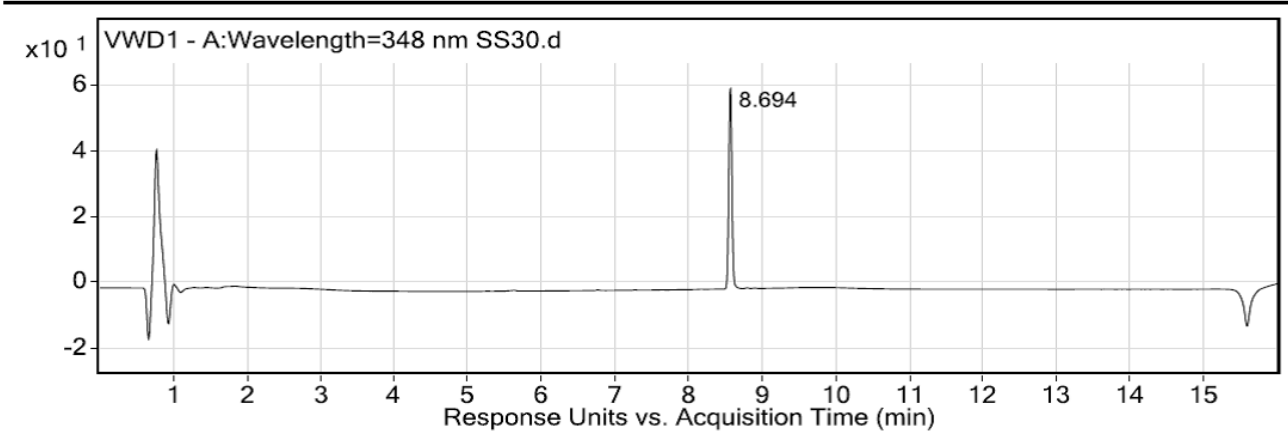

User Spectra

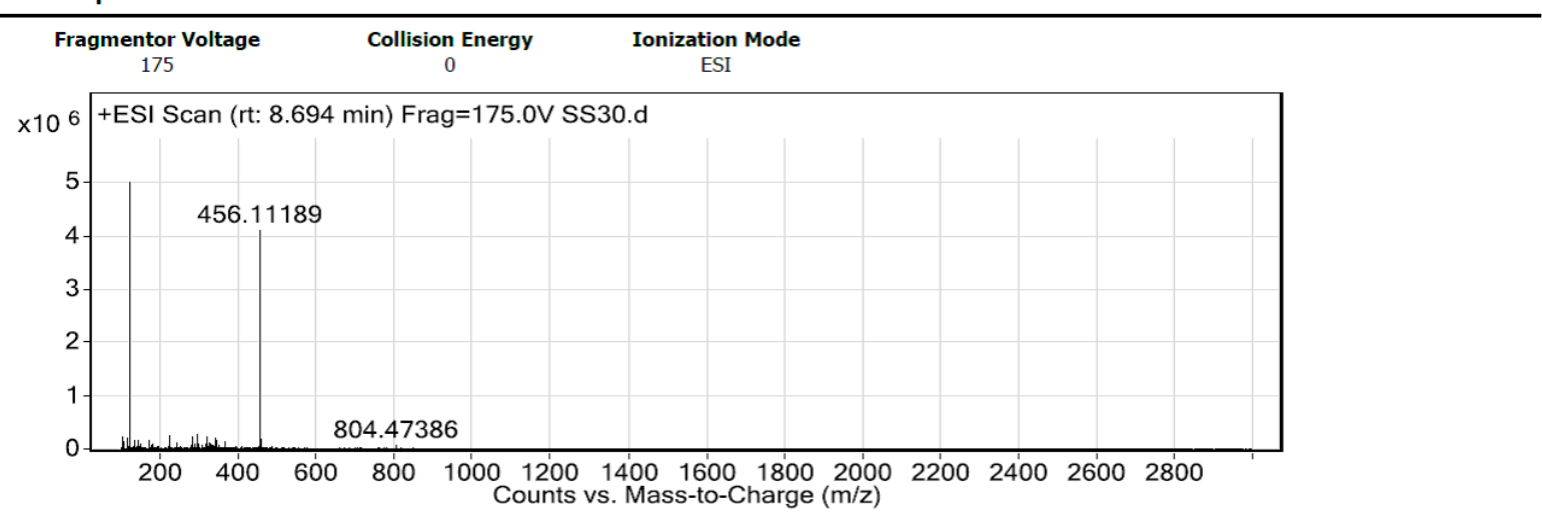

Figure S8. HPLC-MS chromatogram of $(S, S)$-1 after 30 min reaction with MsrA. 


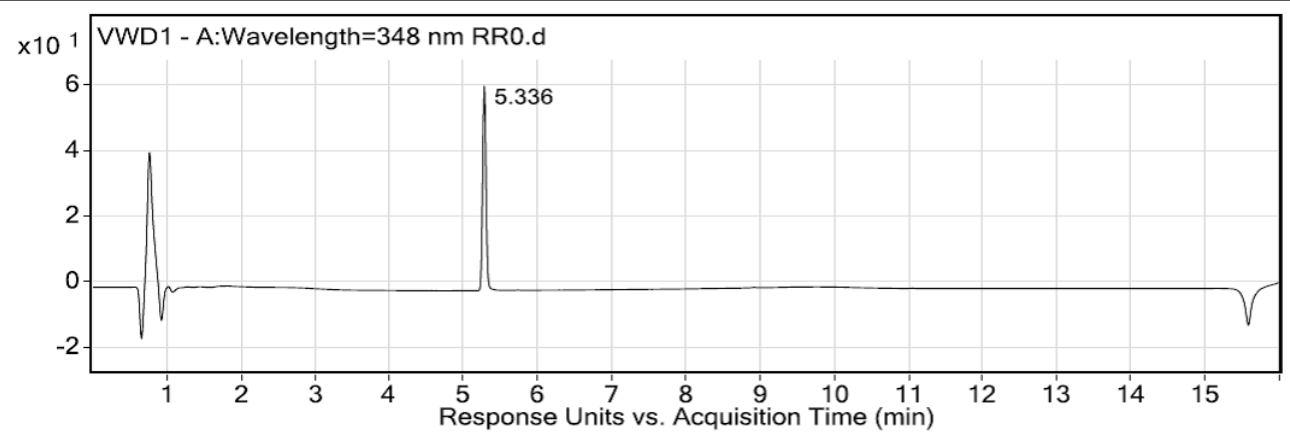

User Spectra

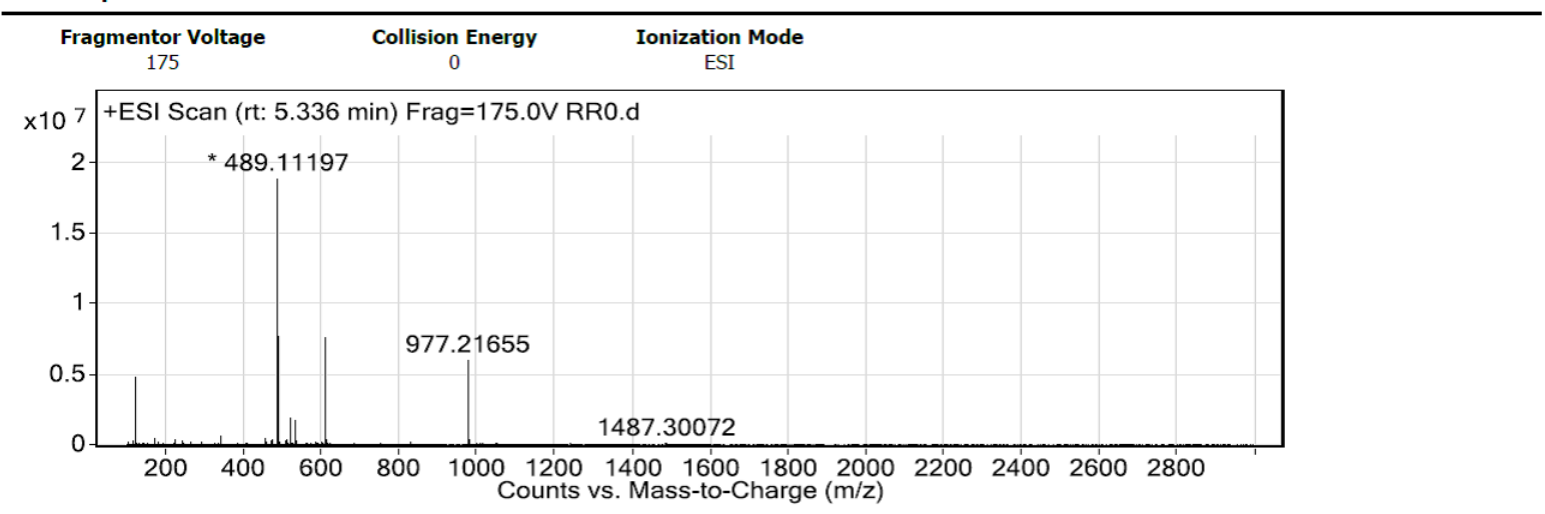

Figure S9. HPLC-MS chromatogram of $(R, R)-\mathbf{1}$ before the reaction with MsrA. 


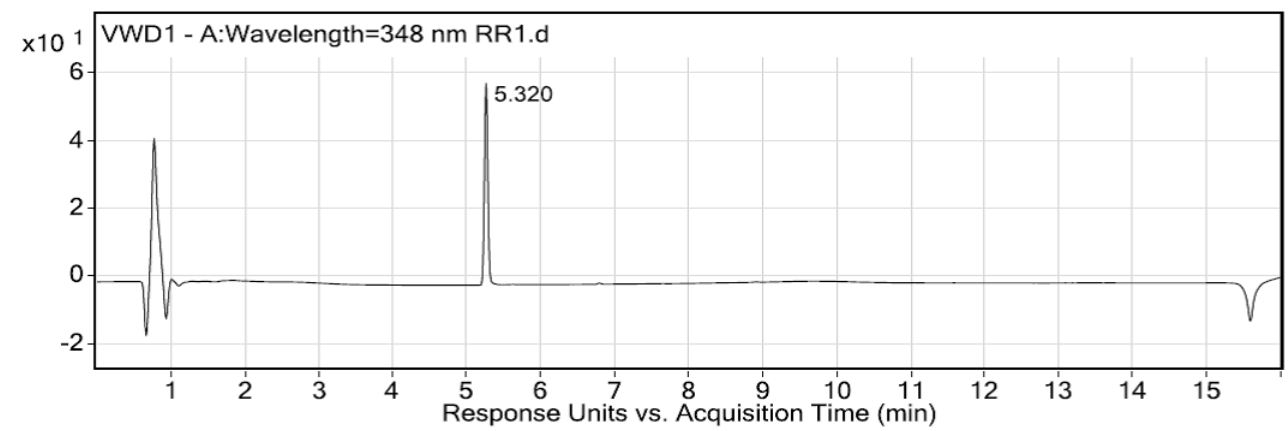

User Spectra

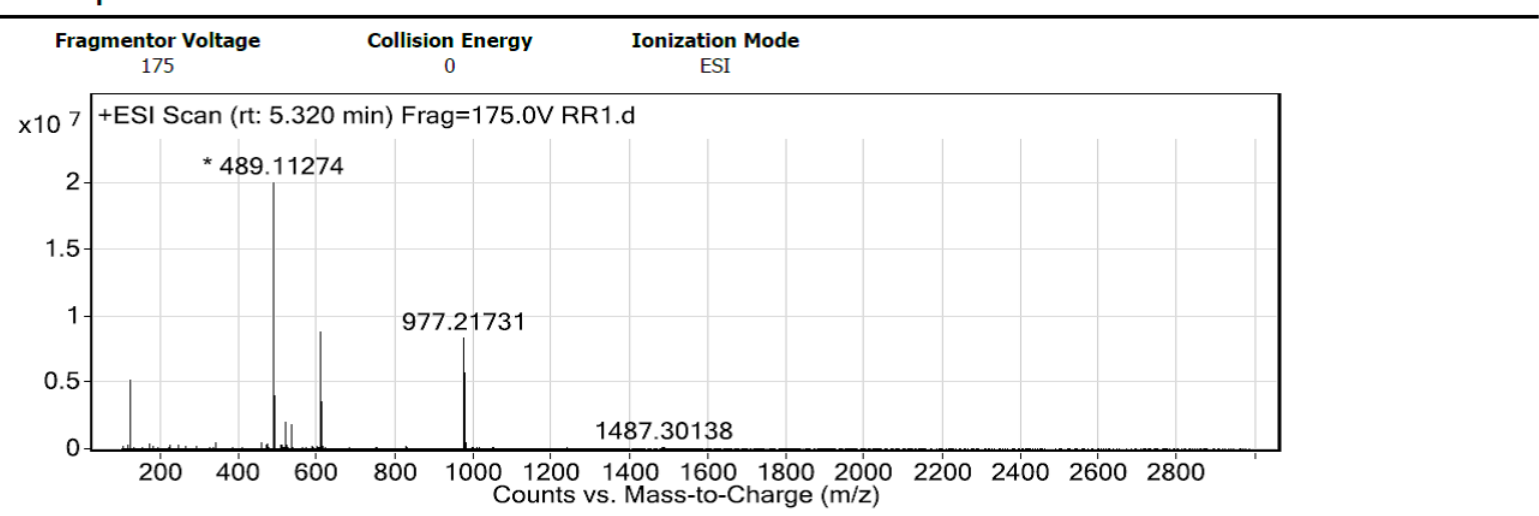

Figure S10. HPLC-MS chromatogram of $(R, R)-1$ after 1 min reaction with MsrA. 


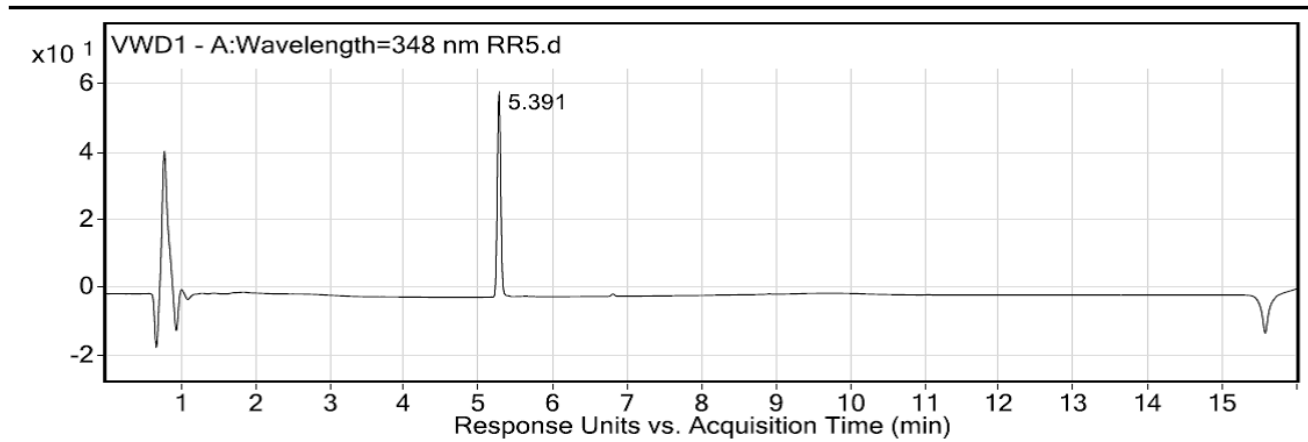

User Spectra

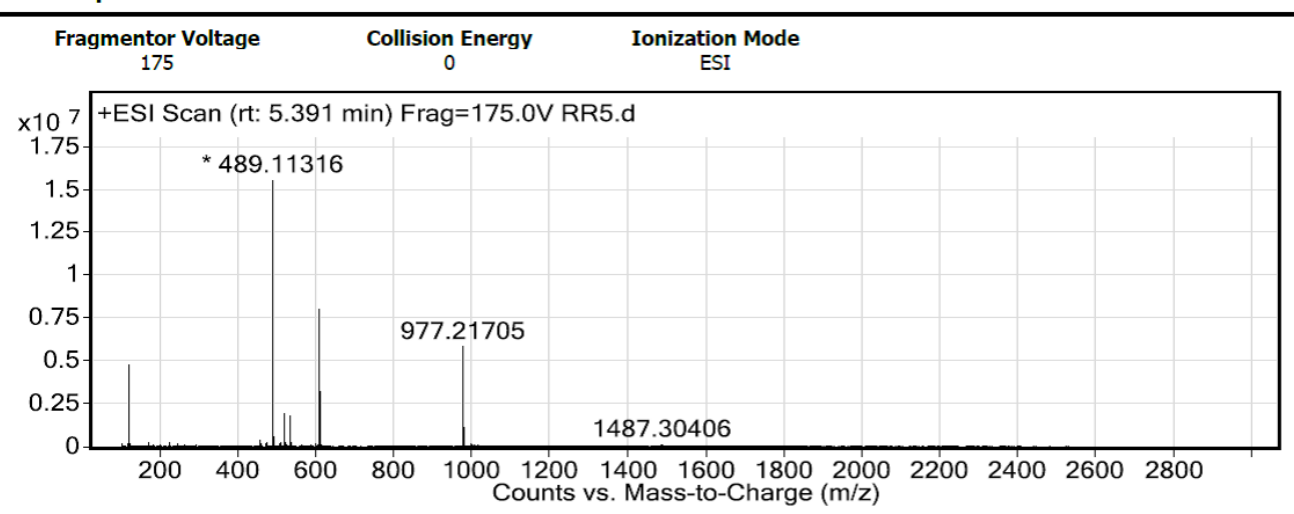

Figure S11. HPLC-MS chromatogram of $(R, R)-1$ after 5 min reaction with MsrA. 


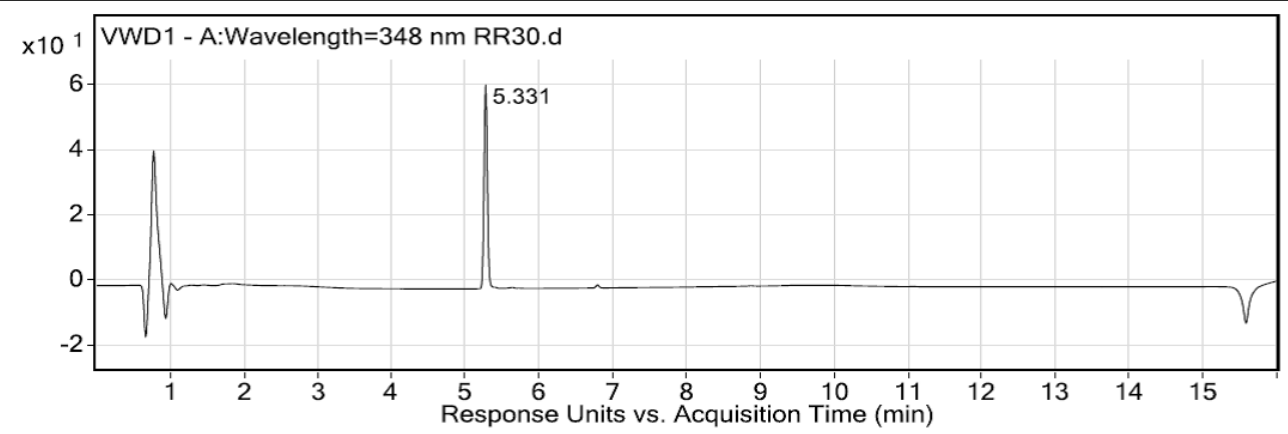

User Spectra

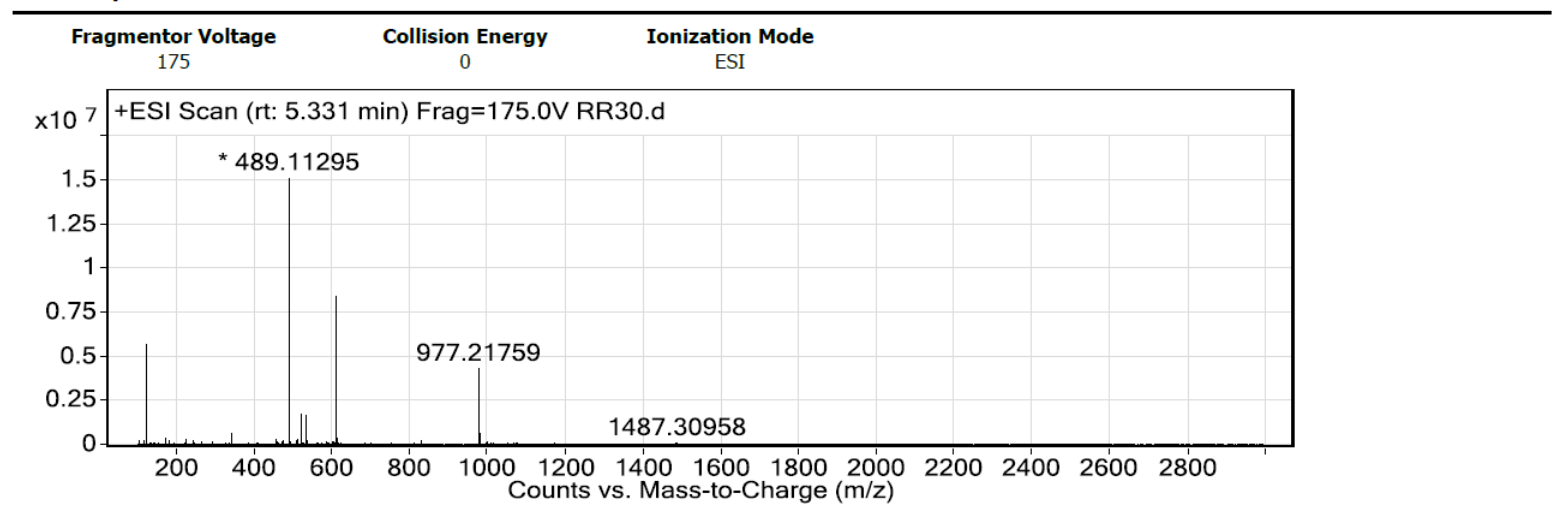

Figure S12. HPLC-MS chromatogram of $(R, R)$-1 after 30 min reaction with MsrA.

(a)

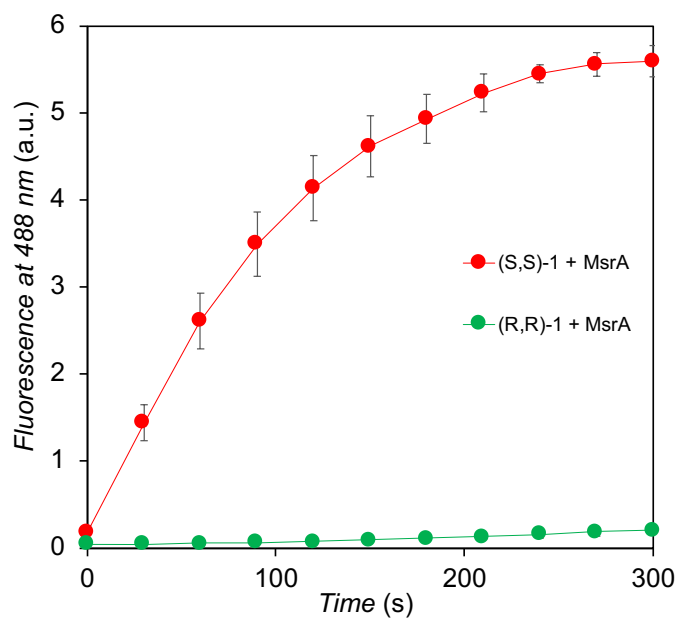

(b)

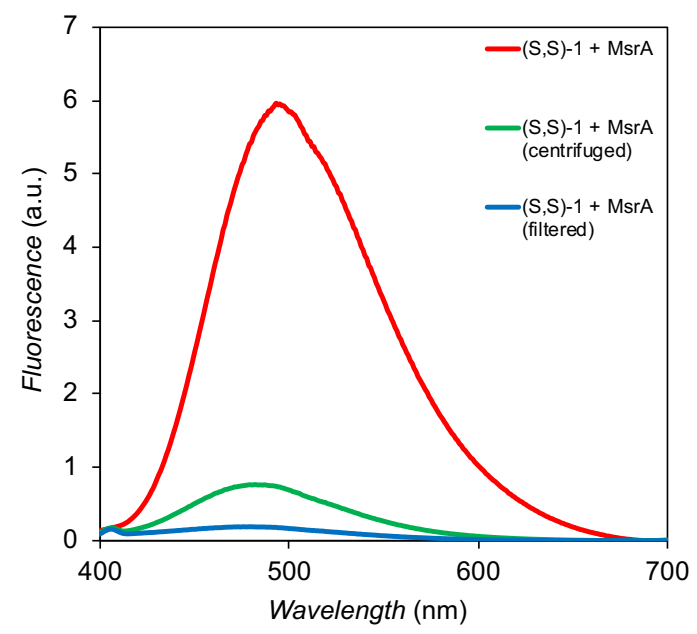

Figure S13. a) in situ monitoring of the reaction progress by fluorescence for $(S, S)-1$ and $(R, R)-1$ with MsrA. b) Emission spectra of samples of (S,S)-1 with MsrA (30 min) before and after centrifugation/filtration. 


\subsection{Imaging of the activity of MsrA immobilized on agarose beads}

Ni-NTA Agarose resin $(10 \mu \mathrm{L}$; ThermoFisher Scientific) was washed with distilled water $(3 \times$ $100 \mu \mathrm{L})$ and His-tag modified $\mathrm{MsrA}^{7}(10 \mu \mathrm{L} ; 42 \mu \mathrm{M}$ in $50 \mathrm{mM}$ Tris buffer, $\mathrm{pH} 8)$ in PBS buffer $\left(100 \mu \mathrm{L} ; 10 \mathrm{mM} \mathrm{Na}_{2} \mathrm{HPO}_{4}, 1.8 \mathrm{mM} \mathrm{KH}_{2} \mathrm{PO}_{4}, 2.7 \mathrm{mM} \mathrm{KCl}, 140 \mathrm{mM} \mathrm{NaCl}, \mathrm{pH} 7.3\right)$ was added. The resulting suspension was gently mixed for $30 \mathrm{~min}$ at room temperature. Then the resin was washed with PBS $(3 \times 200 \mu \mathrm{L})$ and a slurry of $10 \mu \mathrm{L}$ of MsrA immobilized on Ni-NTA Agarose was maintained. $1 \mu \mathrm{L}$ of the slurry was placed on a Petri dish and covered with a solution of $(S, S)-\mathbf{1},(R, R)-\mathbf{1}$ or GreenOx $(100 \mu \mathrm{L}, 50 \mu \mathrm{M}$ for probes $\mathbf{1}, 200 \mu \mathrm{M}$ for GreenOx in Tris buffer $(50 \mathrm{mM}$ Tris, $\mathrm{pH} 8)$ with DTT $(20 \mathrm{mM}))$. The suspension was immediately imaged with Leica 6SD stereomicroscope (Figure S14). Samples were excited at $365 \mathrm{~nm}$ (lamp, 8W) and fluorescence was recorded with Canon EOS 600D (exposition time $0.5 \mathrm{~s})$. Image processing was done in ImageJ software.
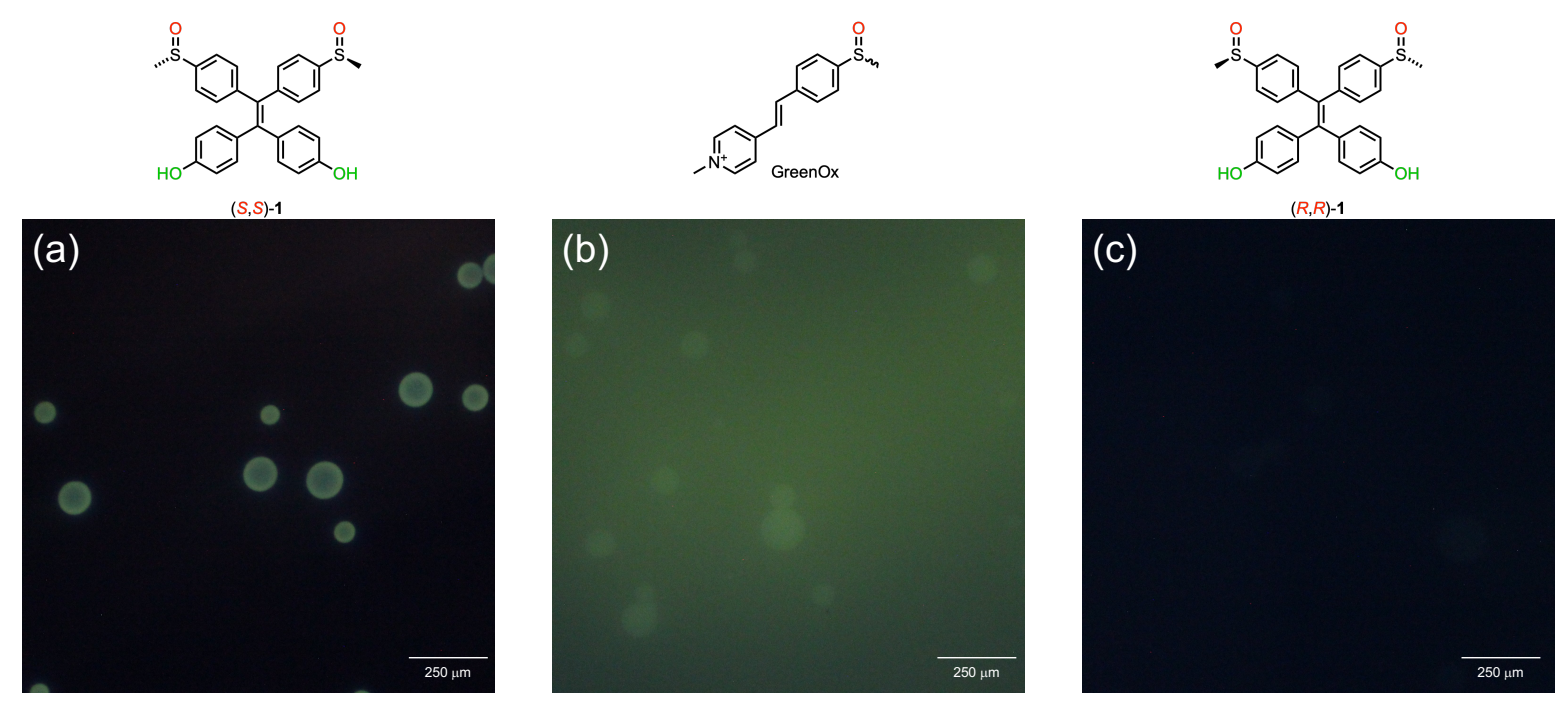

Figure S14. Fluorescent imaging of the activity of MsrA immobilized on agarose beads. a) $(S, S)-1(50 \mu \mathrm{M}), \mathrm{b})$ GreenOx $(200 \mu \mathrm{M})$ and c) $(R, R)-1(50 \mu \mathrm{M})$.

\section{References}

1. V. Nosek, J. Míšek, Chemoenzymatic Deracemization of Chiral Sulfoxides. Angew. Chem. Int. Ed. 2018, 57, 9849-9852.

2. A. Mukhopadhyay, V. K. Maka, J. N. Moorthy, Fluoride-Triggered Ring-Opening of Photochromic Diarylpyrans into Merocyanine Dyes: Naked-Eye Sensing in Subppm Levels. J. Org. Chem. 2016, 81, 7741-7750.

3. Y. R. Bhorge, C.-T. Chang, S.-H. Chang, T.-H. Yan, $\mathrm{CHBr}_{3} / \mathrm{TiCl}_{4} / \mathrm{Mg}$ as an Unusual Nucleophilic $\mathrm{CBr}_{2}$ Carbenoid: Effective and Chemoselective Dibromomethylation of Aldehydes and Ketones. Eur. J. Org. Chem. 2012, 2012, 4805-4810.

4. M. Zhang, Y. Yao, P. J. Stang, W. Zhao, Divergent and Stereoselective Synthesis of Tetraarylethylenes from Vinylboronates. Angew. Chem. Int. Ed. 2020, 59, 20090-20098.

5. V. Nosek, J. Míšek, Enzymatic Kinetic Resolution of Chiral Sulfoxides-An Enantiocomplementary Approach. Chem. Commun. 2019, 55, 10480-10483 
6. T. Baba, T. Ara, M. Hasegawa, Y. Takai, Y. Okumura, M. Baba, K. A. Datsenko, M. Tomita, B. L. Wanner, H. Mori, Construction of Escherichia coli K-12 In-Frame, SingleGene Knockout Mutants: The Keio Collection. Mol. Syst. Biol. 2006, 2, 2006.0008.

7. V. Tarallo, K. Sudarshan, V. Nosek, J. Míšek, Development of a Simple High-Throughput Assay for Directed Evolution of Enantioselective Sulfoxide Reductases. Chem. Comm. 2020, 56, 5386-5388.

8. C. H. R. Martínez, C. Dardonville, Rapid Determination of Ionization Constants ( $\left.\mathrm{p} K_{\mathrm{a}}\right)$ by UV Spectroscopy Using 96-Well Microtiter Plates. ACS Med. Chem. Lett. 2013, 4, 142 145. 
2. Copies of ${ }^{1} \mathrm{H}$ and ${ }^{13} \mathrm{C}$ NMR spectra

${ }^{1} \mathrm{H}$ NMR (400 MHz, $\mathrm{CDCl}_{3}$ ) of (S)-1-bromo-4-(methylsulfinyl)benzene

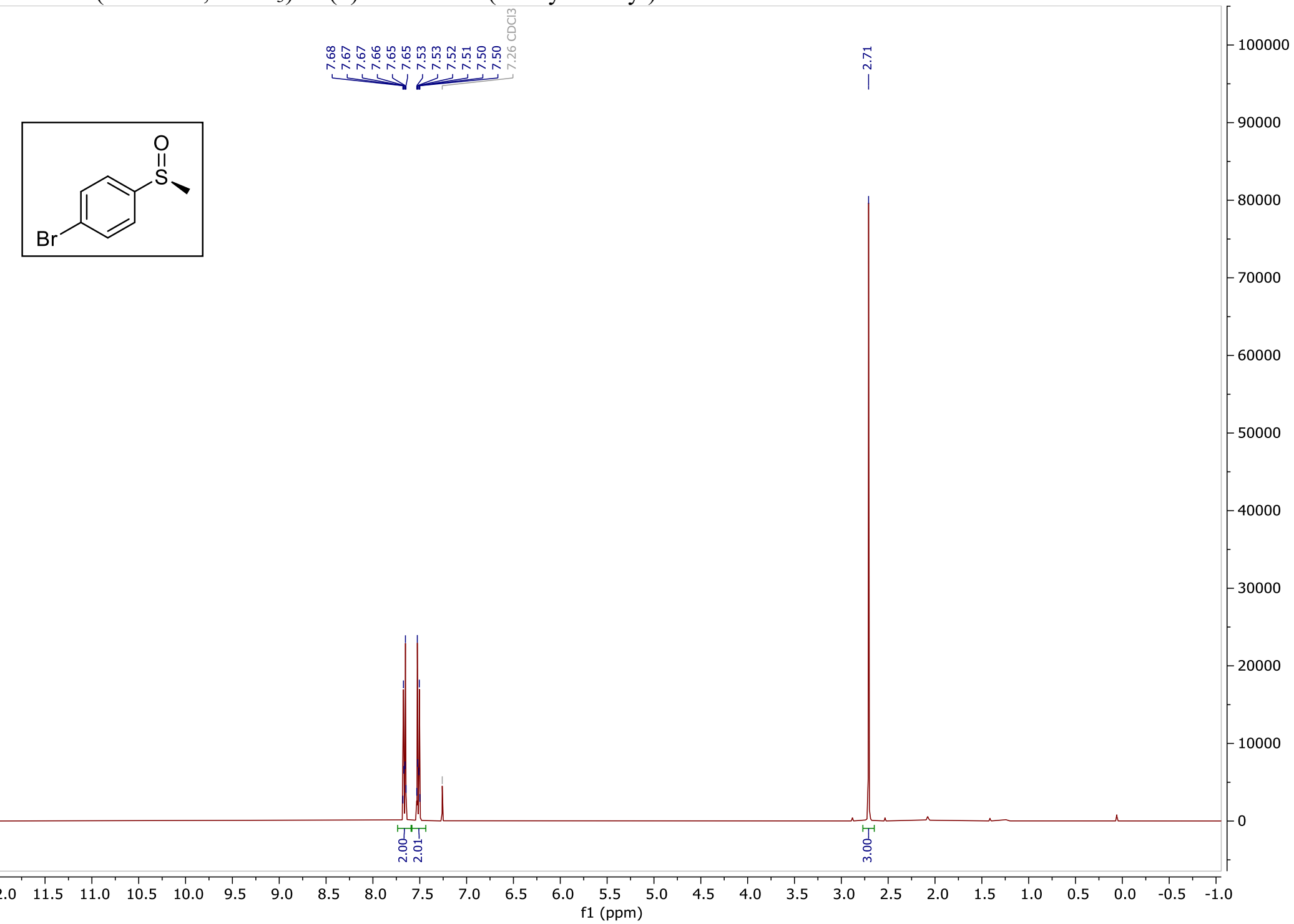


${ }^{1} \mathrm{H}$ NMR $\left(400 \mathrm{MHz}, \mathrm{CDCl}_{3}\right)$ of 4

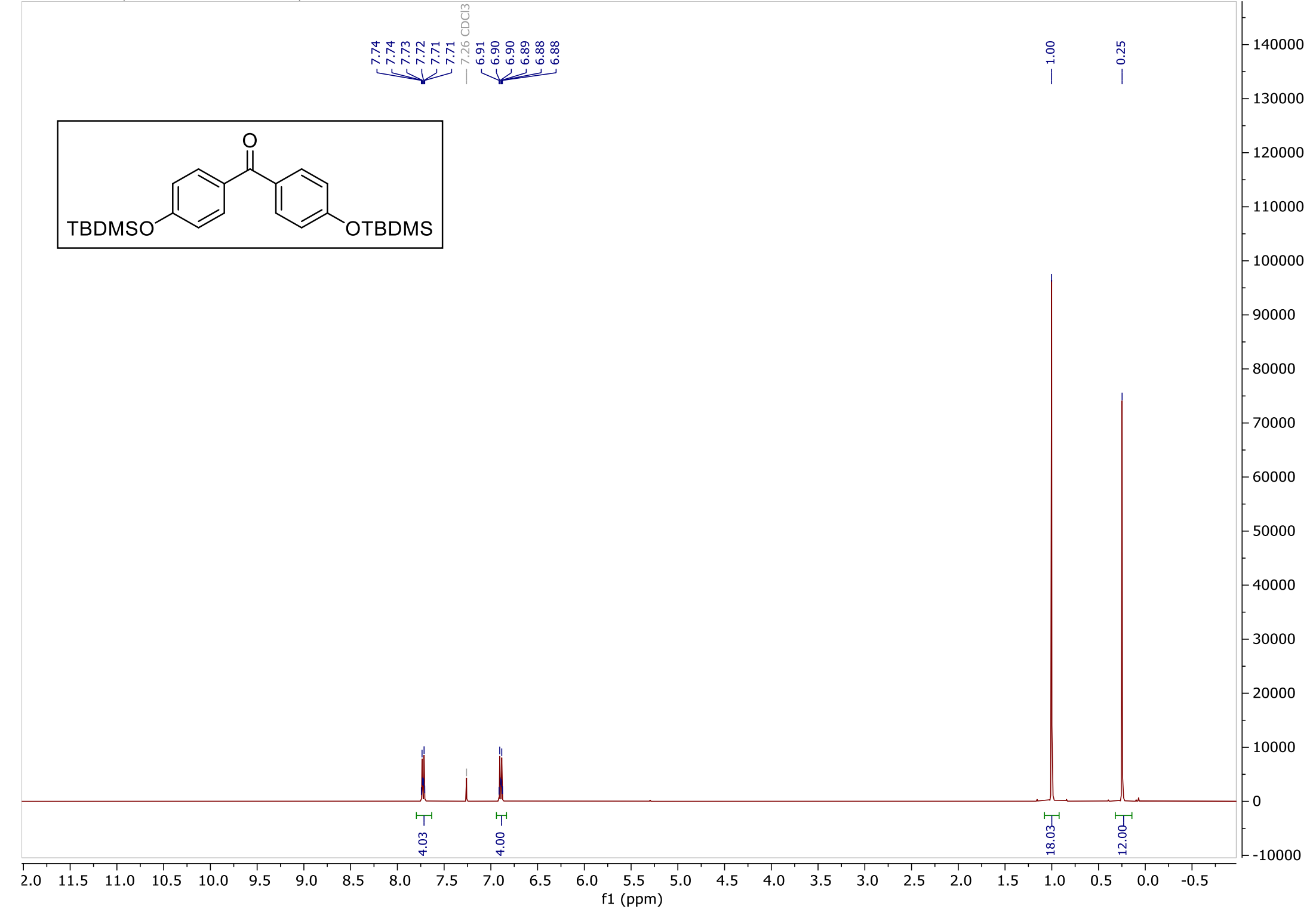




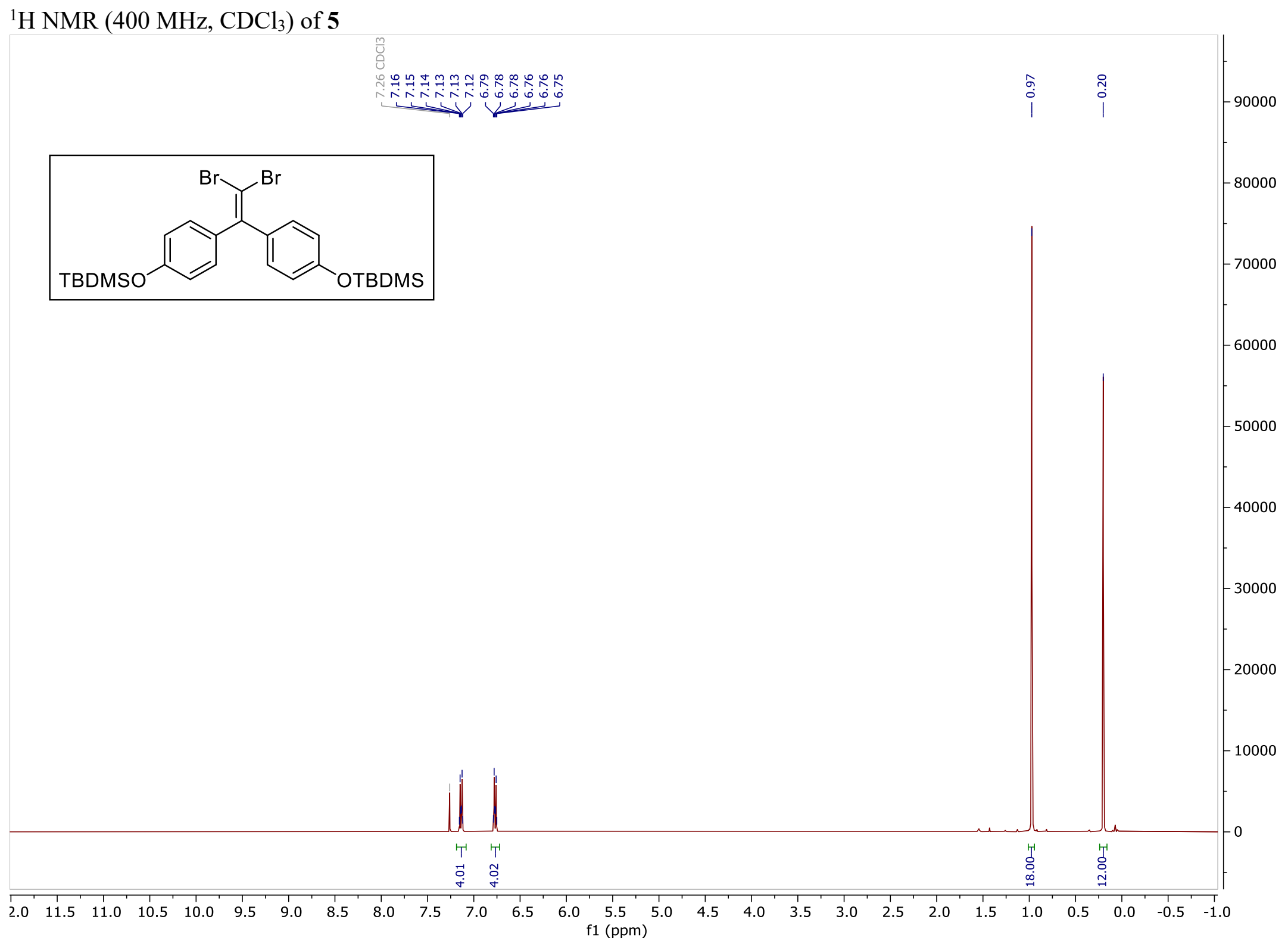


${ }^{13} \mathrm{C}$ NMR $\left(101 \mathrm{MHz}, \mathrm{CDCl}_{3}\right)$ of $\mathbf{5}$

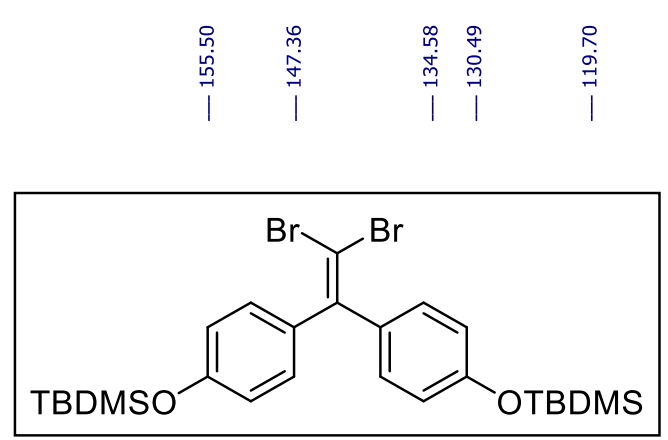

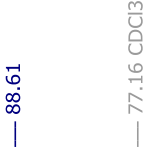

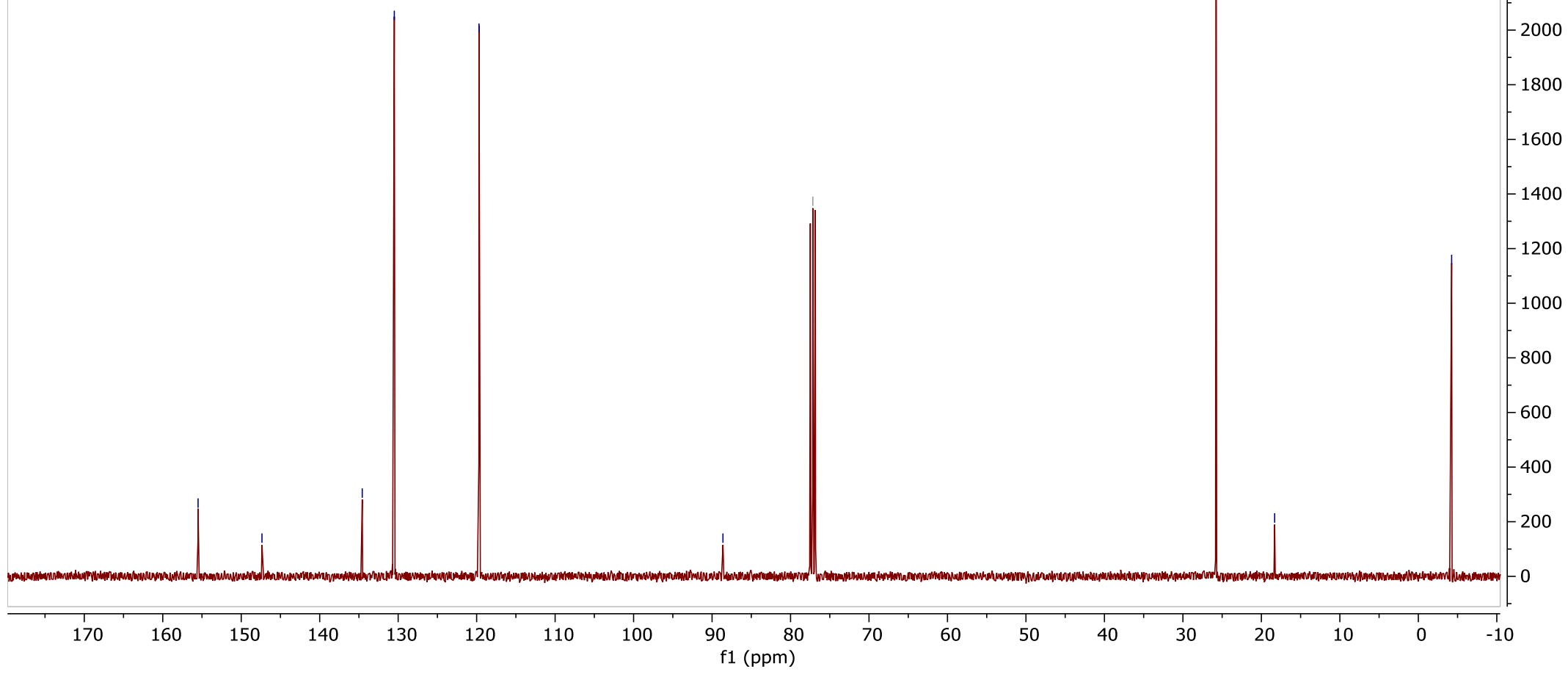




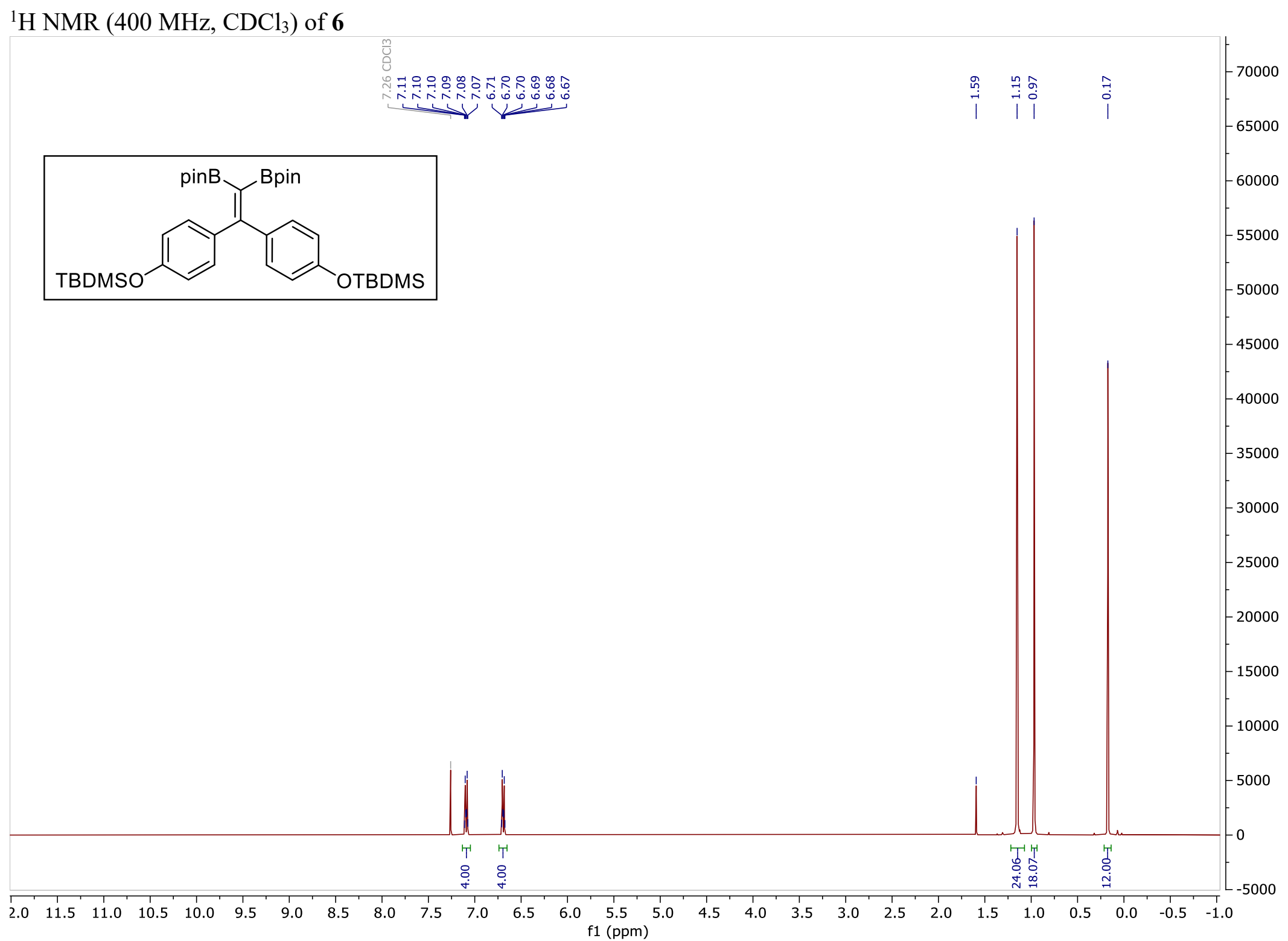


${ }^{13} \mathrm{C}$ NMR $\left(101 \mathrm{MHz}, \mathrm{CDCl}_{3}\right)$ of 6

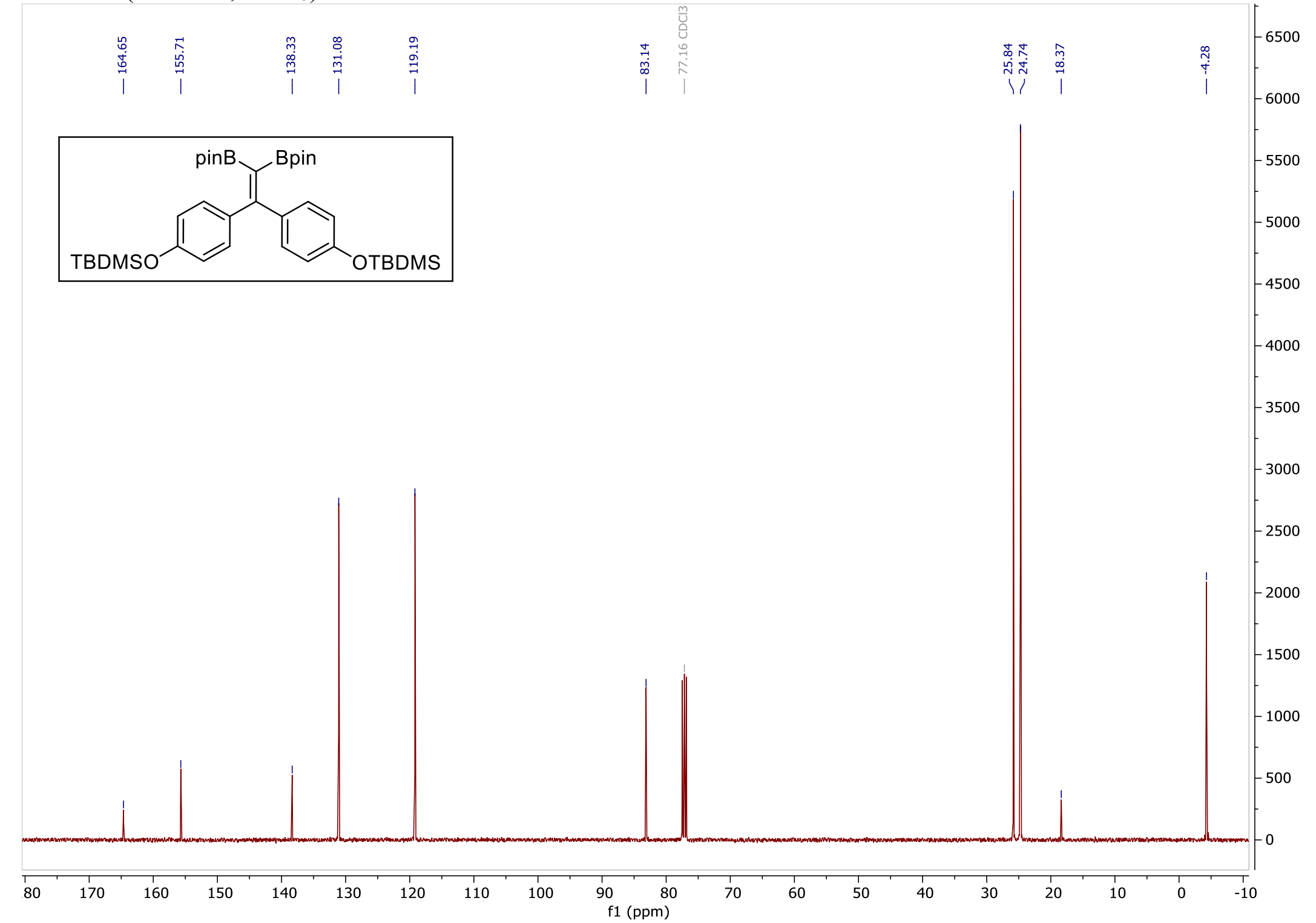


${ }^{1} \mathrm{H}$ NMR (400 MHz, $\left.\mathrm{CD}_{3} \mathrm{OD}\right)$ of 2

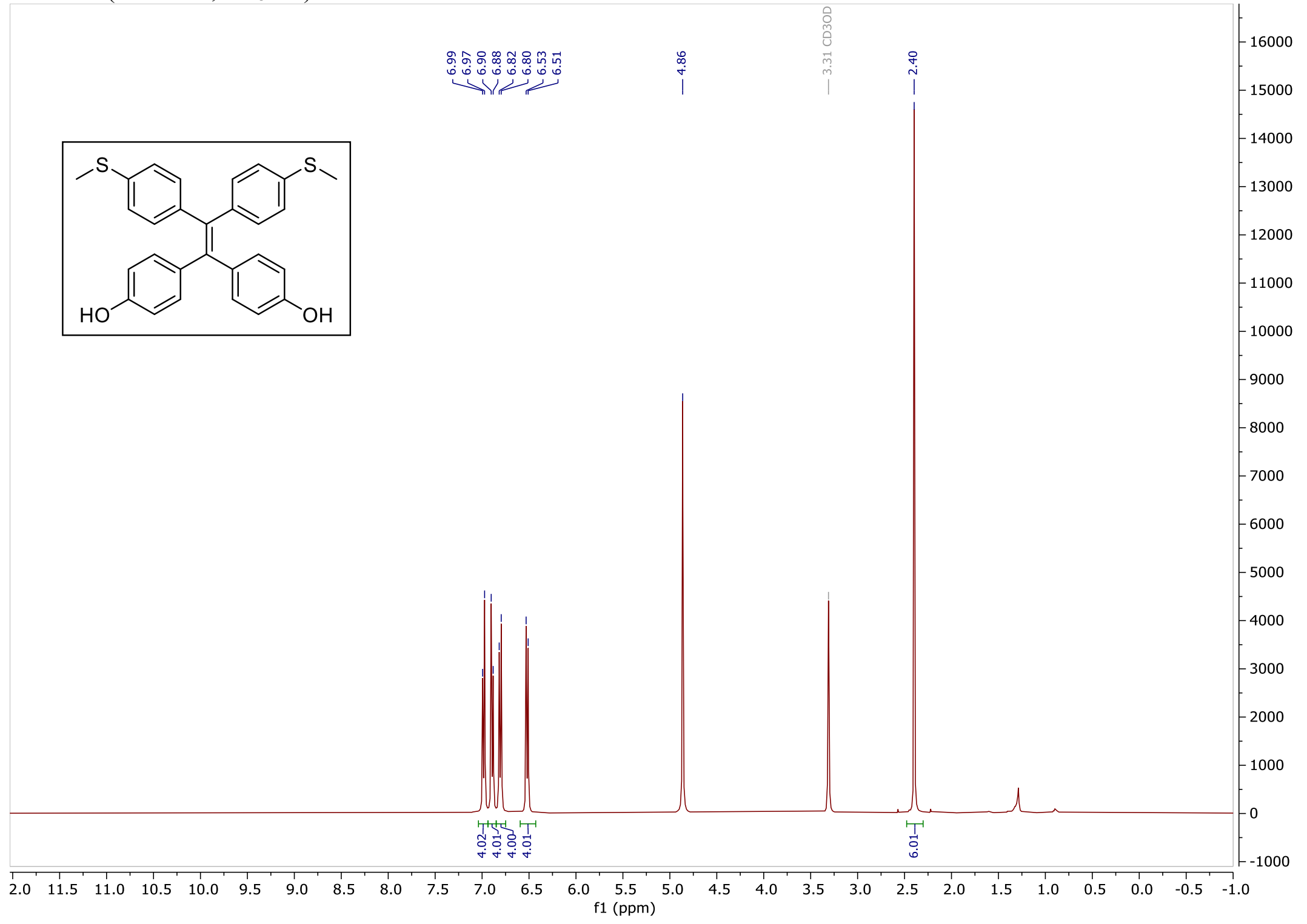


${ }^{13} \mathrm{C}$ NMR (101 MHz, $\left.\mathrm{CD}_{3} \mathrm{OD}\right)$ of 2

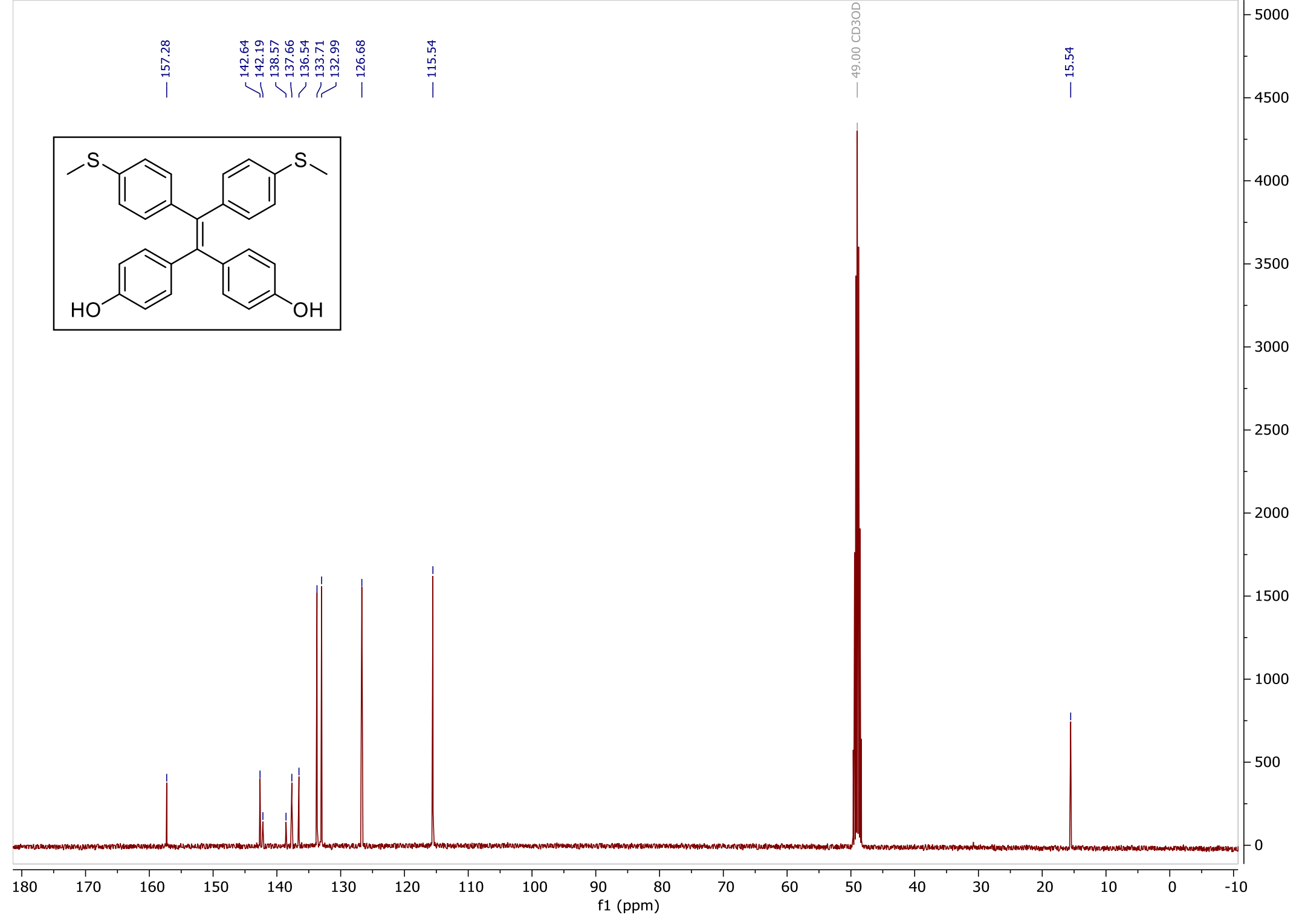


${ }^{1} \mathrm{H}$ NMR (400 MHz, $\left.\mathrm{CD}_{3} \mathrm{OD}\right)$ of $r a c-1$

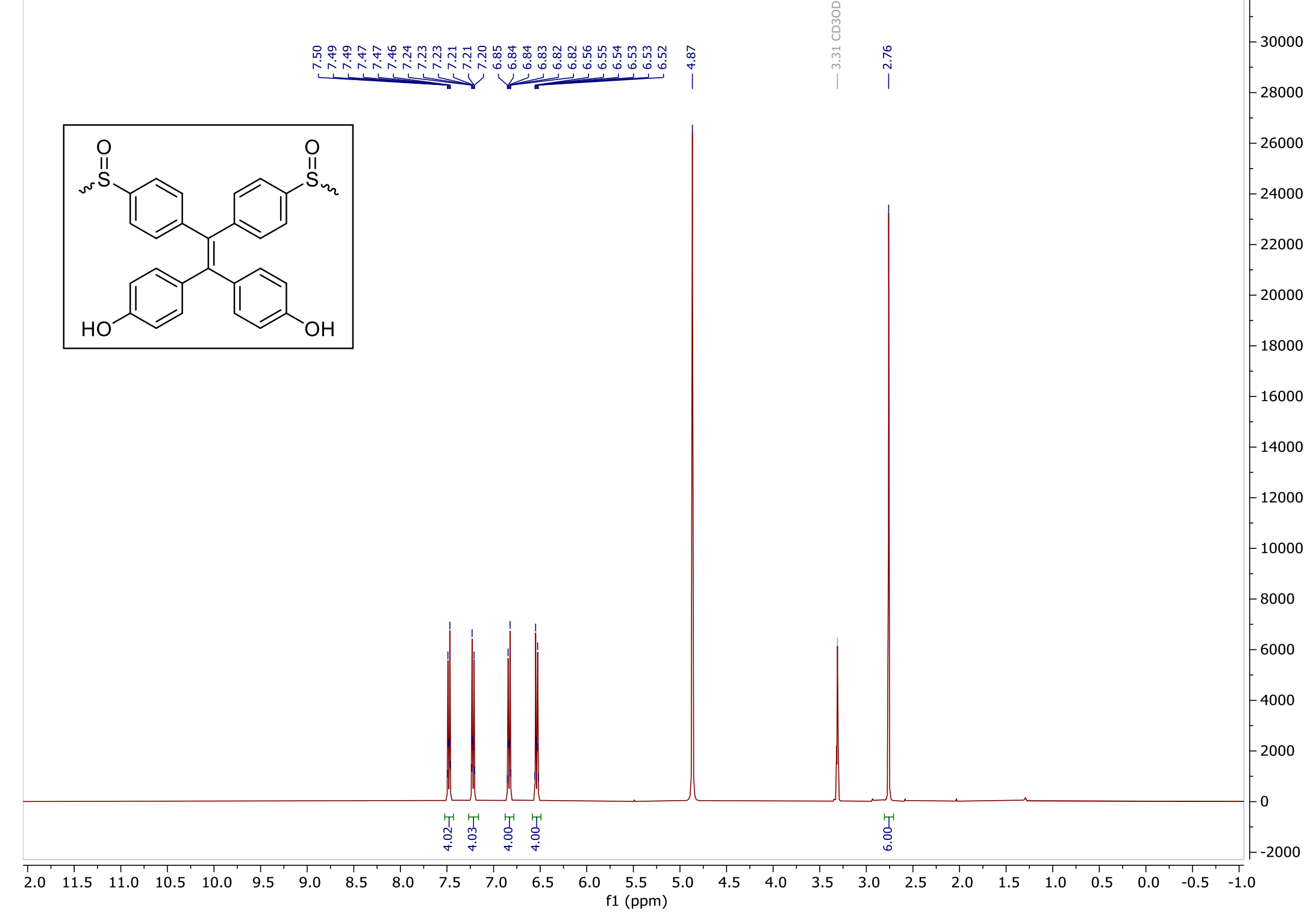


${ }^{13} \mathrm{C}$ NMR (101 MHz, $\left.\mathrm{CD}_{3} \mathrm{OD}\right)$ of $r a c-1$

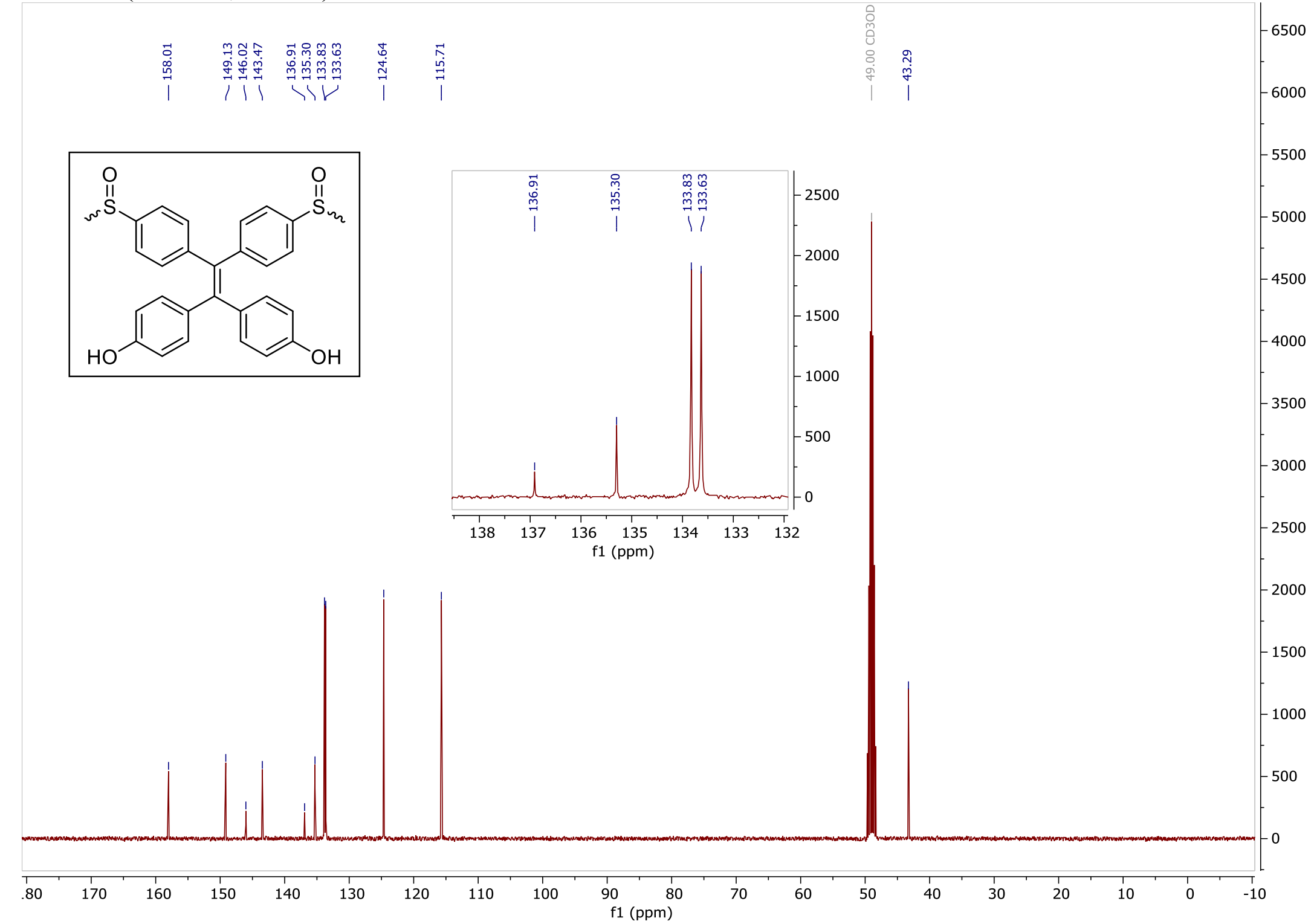


${ }^{1} \mathrm{H}$ NMR (600 MHz, $\left.\mathrm{CD}_{3} \mathrm{OD}\right)$ of $(S, S)-\mathbf{1}$

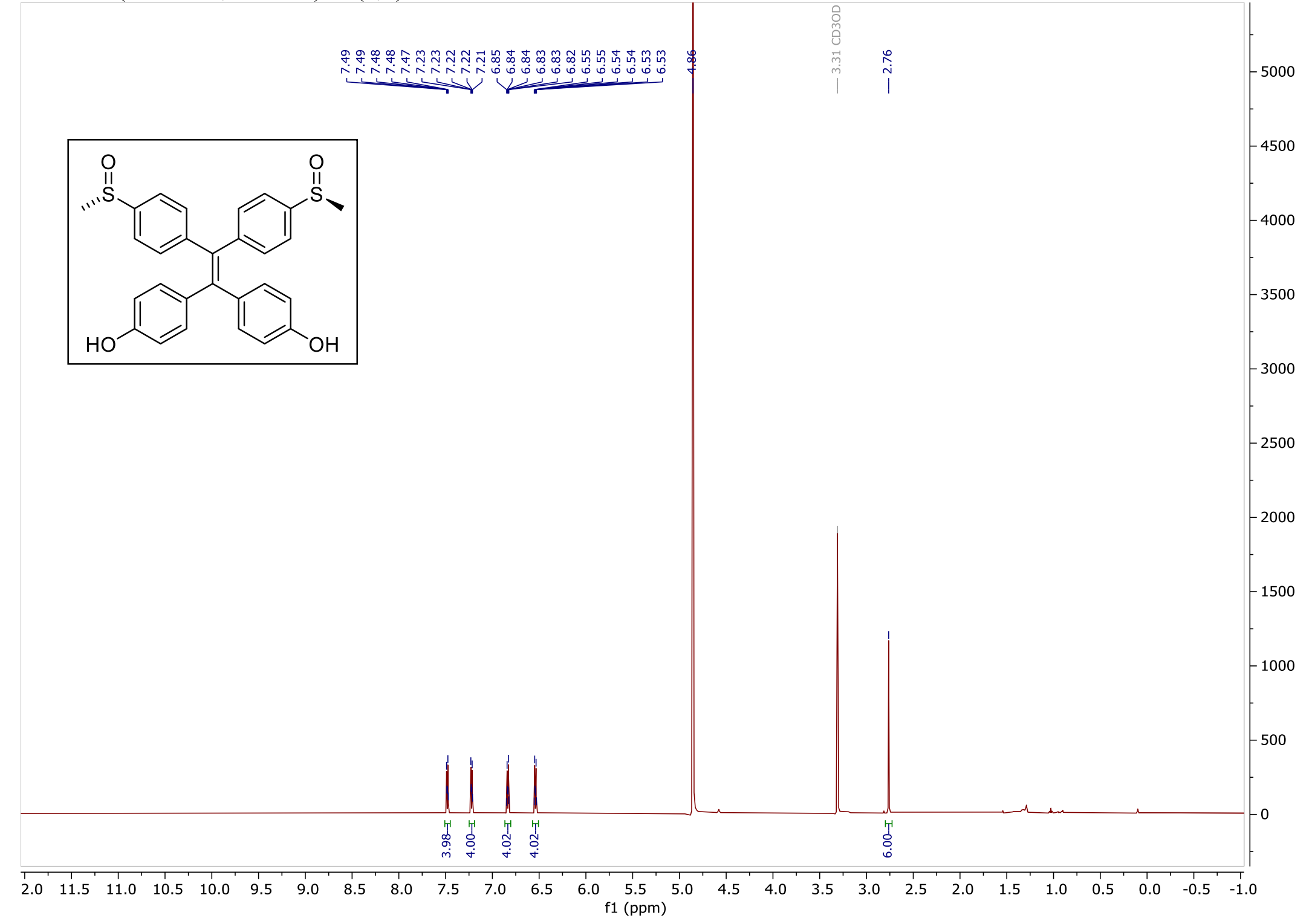


${ }^{13} \mathrm{C}$ NMR $\left(151 \mathrm{MHz}, \mathrm{CD}_{3} \mathrm{OD}\right)$ of $(S, S)-\mathbf{1}$

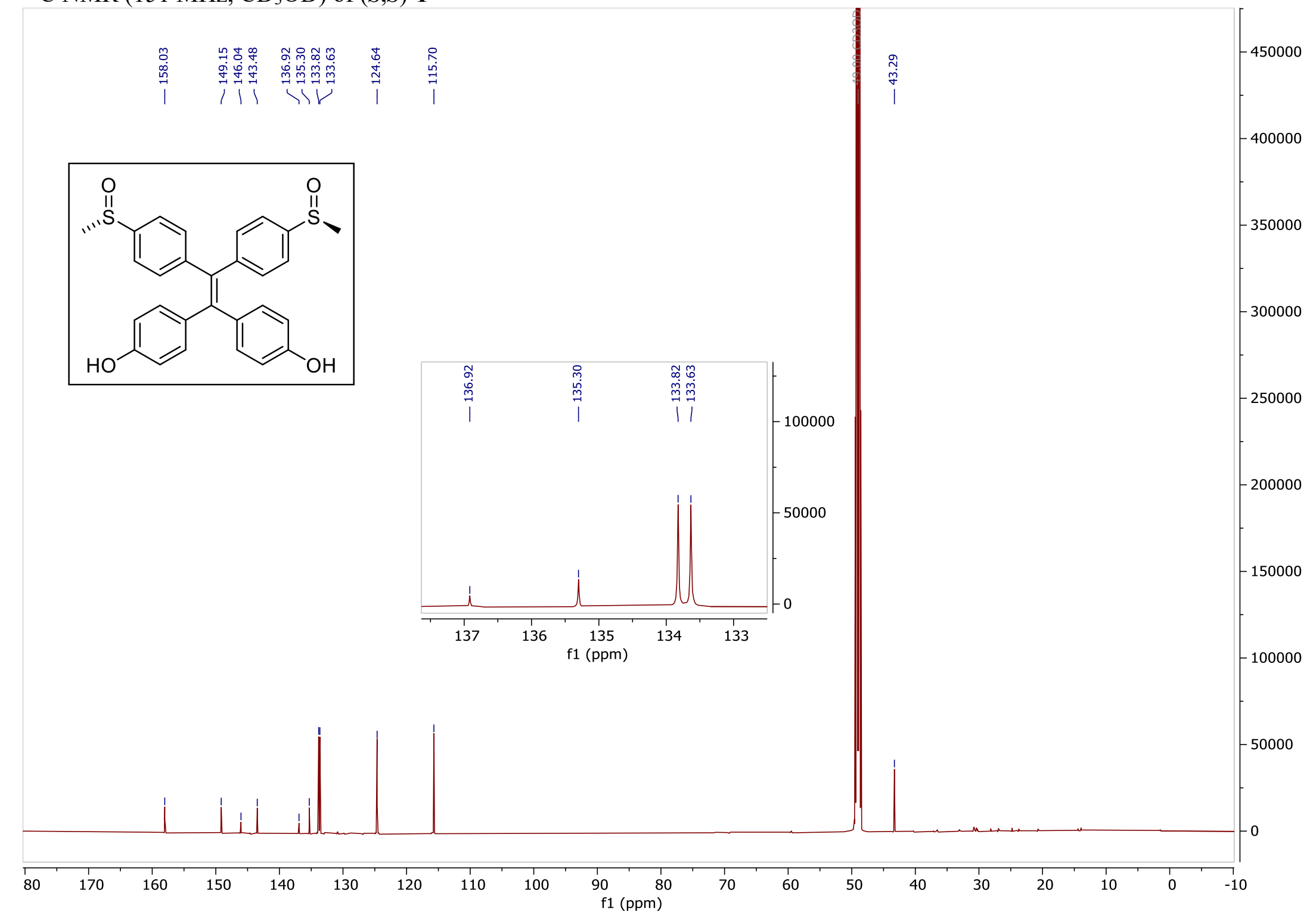


${ }^{1} \mathrm{H}$ NMR (600 MHz, $\left.\mathrm{CD}_{3} \mathrm{OD}\right)$ of $(R, R)-1$

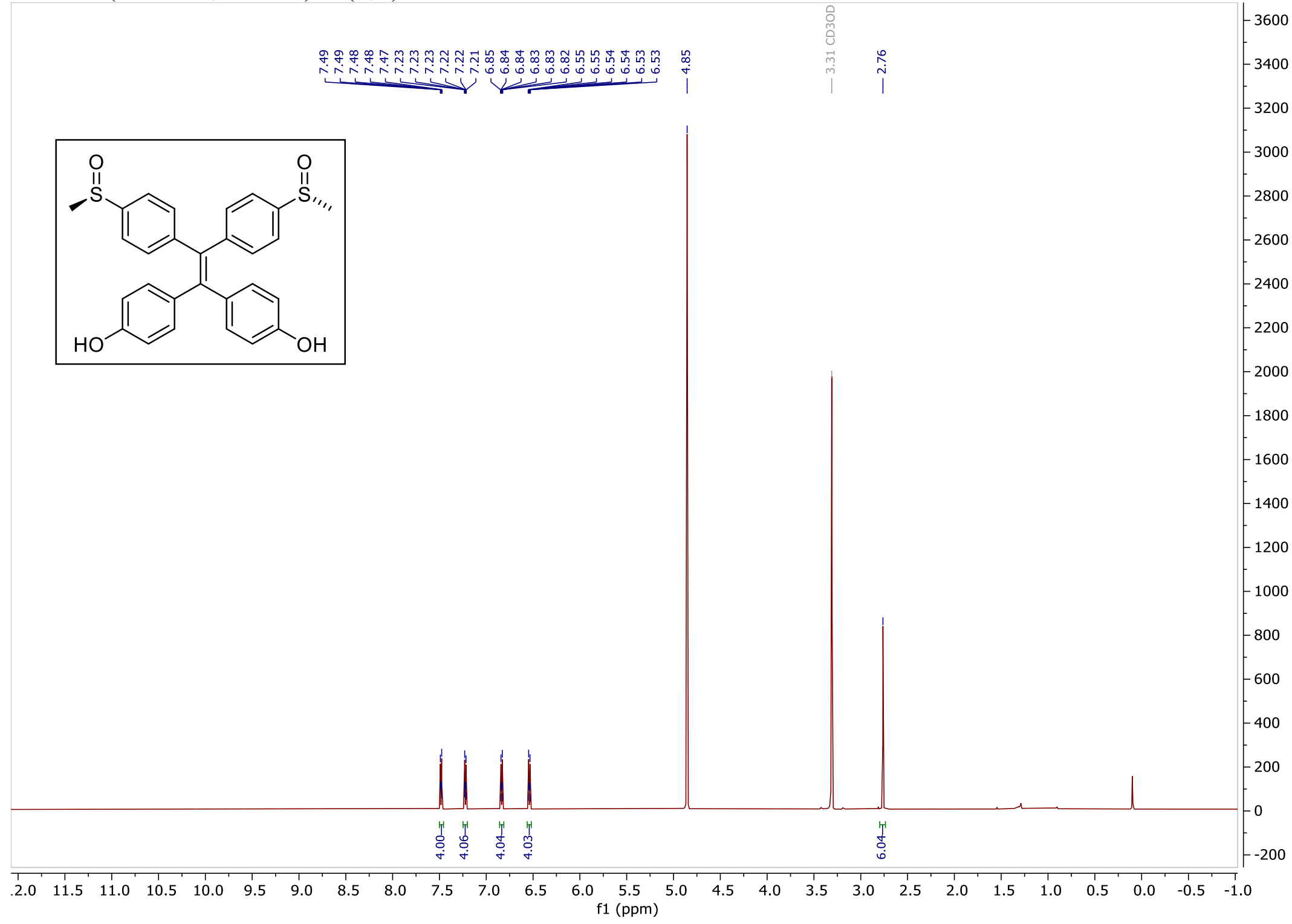


${ }^{13} \mathrm{C}$ NMR (151 MHz, $\left.\mathrm{CD}_{3} \mathrm{OD}\right)$ of $(R, R)-\mathbf{1}$

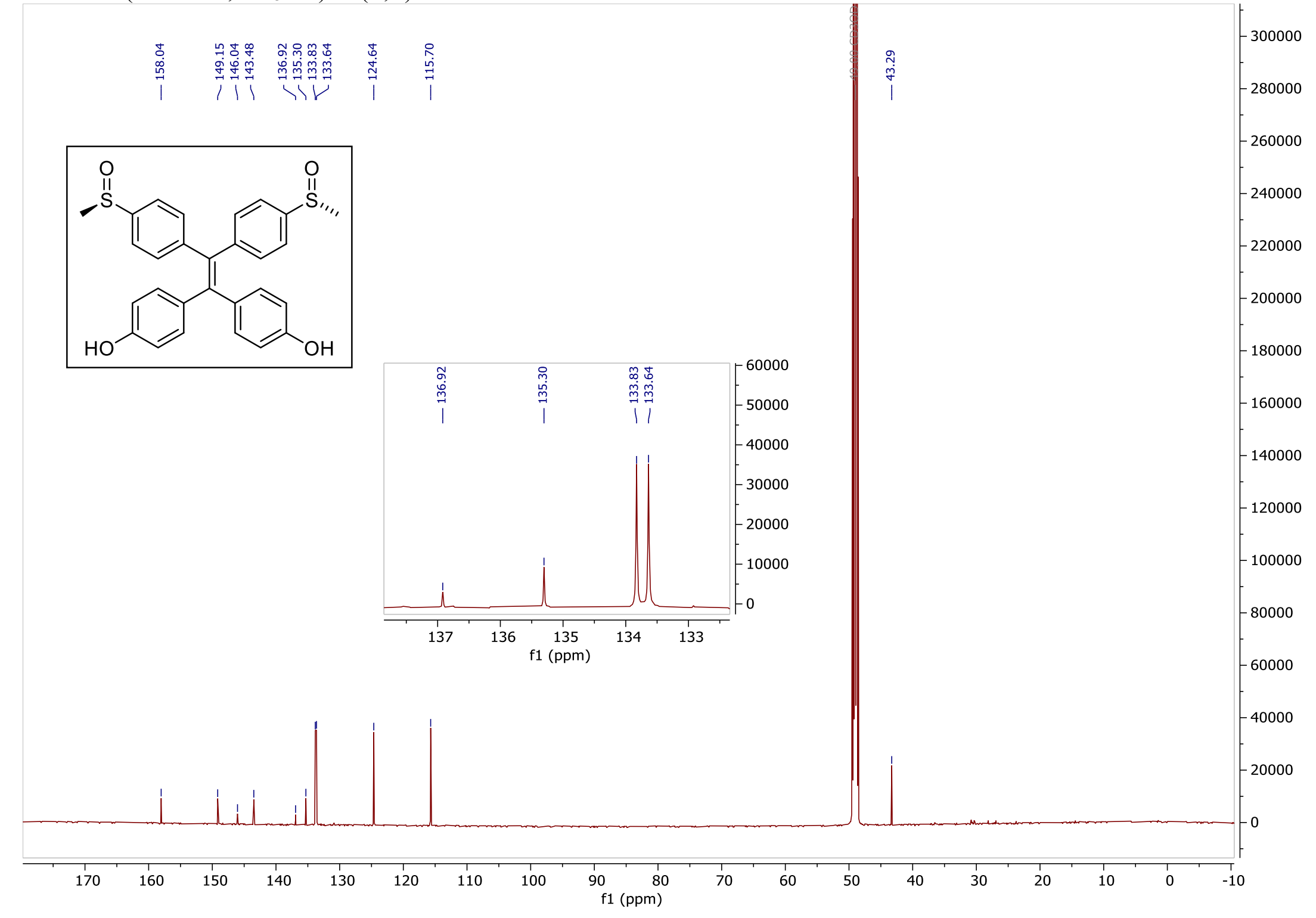

